\title{
Body Metamorphosis and Animality: Volatile Bodies and Boulder Artworks from Lepenski Vir
}

\author{
Dušan Borić
}

This article discusses the notion of body metamorphosis as a theory of phenomenal change by examining carved representational and 'aniconic' boulders from Lepenski Vir and other Meso-Neolithic sites in the Danube Gorges. The voluminous size of the boulders at Lepenski Vir, the way in which they occupy the three-dimensional space within buildings and around hearths, and the carvings over their surfaces suggest that they were understood as volatile bodies, undergoing continuous metamorphoses. The relationship between the seasonal recurrence of the Danube's migratory fish and these boulders is explored through the notion of animality. These boulders indicate prescribed stages of life-cycle metamorphosis that affected inextricably-linked realms of human and animal worlds. Prescribed stages of social embodiment at Lepenski Vir are discerned by looking at the archaeological context of representational boulders that sometimes directly commemorate particular deceased individuals. The possibility that boulder artworks acted as sacred heirlooms of particular buildings is connected to the social efficacy they might have acquired.

\begin{abstract}
The reference to the 'arch-materialist Diderot' derives doubtless from the following letter, which I discovered thanks to Madame Elisabeth de Fontenay: 'People who loved each other in life and ask to be buried side by side are not perhaps so mad as is generally supposed. Perhaps their ashes press together, commingle, and unite ... What do I know? Perhaps they have not lost all feeling, all memory of their original state; perhaps a remnant of warmth and life continues to smolder in them. O Sophie, if I might still hope to touch you, feel you, unite with you, merge with you when we are no more, if there were a law of affinity between our elements, if we were destined to form a single being, if in the train of centuries I were meant to become one with you, if the molecules of your moldering lover had the power to stir and move about and go in search of your molecules dispersed in nature! Leave me this wild fancy; it is dear to me, it would ensure me an eternity in you and with you ...' (Kiš 1989, 199)
\end{abstract}

Archaeologists frequently come across artistic expressions of ancient dwellers that depict hybrids, with both human and animal features merged into a single form of being. The commonsense understanding of such examples is that they may indicate complex associations between humans and certain types of animals. But, are there ways to facilitate more sophisticated and detailed insights about what are universal and common elements of such examples of shape-shifting? In this context, a combined discussion about the notions of body metamorphosis and human animality may help us shape a nuanced theoretical approach to animal-human hybrid depictions.

This article focuses on the imagery and the archaeological context of boulder artworks from the Meso-Neolithic site of Lepenski Vir, situated in the Danube Gorges of the north-central Balkans. The most notable feature of the representational boulders from this site are depictions of hybrid beings with mixed human and fish attributes. Likewise, the pattern of decoration on the surfaces of all boulders, their voluminous size and the specifics of their placement indicate their body-like character, closely connecting boulders to the treatment of dead bodies at this site. Moreover, in some instances representational 


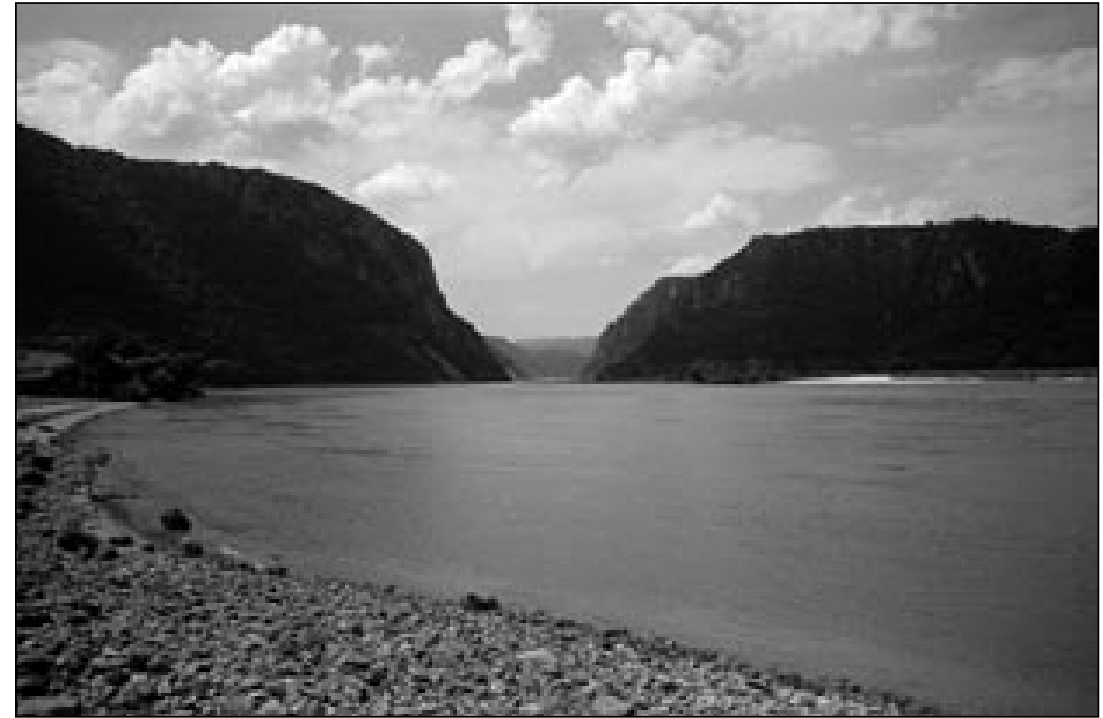

Figure 1. Landscape of the Danube Gorges in the vicinity of the archaeological site of Hajdučka Vodenica, Lower Gorge (photo: B. Jovanović). dition, I indicate an anthropological approach to the study of 'indigenous art'. The theoretical argument continues by examining various sources pertinent to the issue of body metamorphosis and animality. Here I am making explicit references, on one hand, to the field of study known as body theory and, on the other hand, to Georges Bataille's notion of animality. These theoretical insights are examined against the grain of Lepenski Vir examples, with abundant evidence of human-fish associations. Finally, the question of the social efficacy of boulders from Lepenski Vir is tackled by engendering their identities primarily on the basis of representational boulders and their archaeological context. and non-representational boulders commemorate particular burials. It has previously been suggested that the sculptured boulders of the cultural tradition in the Danube Gorges represented sacred heirlooms of buildings/houses that objectified particular social groupings (e.g. Srejović 1969; 1972; Srejović \& Babović 1983; Chapman 1993; Borić 2002a). In this article, however, I would like to move beyond functional discussions of these artworks by also examining the contextual and cognitive logic of this artistic tradition seen as a coherent stylistic system.

The following discussion revolves around two main assumptions: first, the close affinity between the deceased body and boulders and, second, the objectification of associations between humans and fish. On one hand, I use the concept of body metamorphosis to underline the processuality of corporeal embodiments, while, on the other hand, the notion of animality (sensu Bataille) helps in exposing the base materiality of the body 'Other' that perpetuates the change of form. I aim to show that certain elements of the theoretical approach used in this case study can be relevant for and applicable to the wider field of body theory and various archaeological case studies. Building around the idea of the 'power of images' (Freedberg 1989), i.e. the cognitive salience of artworks, a suggestion will be made that the boulders from this site might have embodied effective social (relational) agency (cf. Gell 1998).

In the following section, I present some relevant data with regard to patterns and dating of boulder artworks from Lepenski Vir. After an overview of previous interpretations offered for this 'artistic' tra-

\section{Boulder artworks at Lepenski Vir: patterns and dating}

The Meso-Neolithic archaeological sequence in the Danube Gorges (Fig. 1) of the north-central Balkans (Fig. 2) and the type-site of Lepenski Vir are widely recognized in European Prehistory (e.g. Srejović 1969; 1972; Radovanović 1996; Borić 1999; 2002b,c; Tringham 2000). This sequence covers a long time span of c. 10,000 to 5500 cal. BC arguably with elements of both continuous cultural identity and important diachronic changes in the course of the bracketed period (cf. Radovanović 1996; Borić 1999; 2002b,c; 2003).

The main source for the following discussion of boulder artworks from Lepenski Vir is Srejović \& Babović's (1983) detailed catalogue of boulders and mortars from this site (see Table 1).

The artistic tradition of sculpted boulders ${ }^{1}$ is unique to the region of the Danube Gorges and primarily to the site of Lepenski Vir. A smaller number of strictly non-representational boulders have been found at several other sites in the region. ${ }^{2}$ Most of the representational and aniconic boulders found at Lepenski Vir were found at the rear of rectangular hearths of trapezoidal buildings. Some buildings, however, lacked either boulders or mortars or both (Figs. 3-4).

The date for the appearance of the tradition of boulder artworks could not be established with certainty, and these objects are primarily dated on the basis of their contextual association with architectural features, in certain instances being architectural parts of buildings, as in the case of the hearth of House 43 


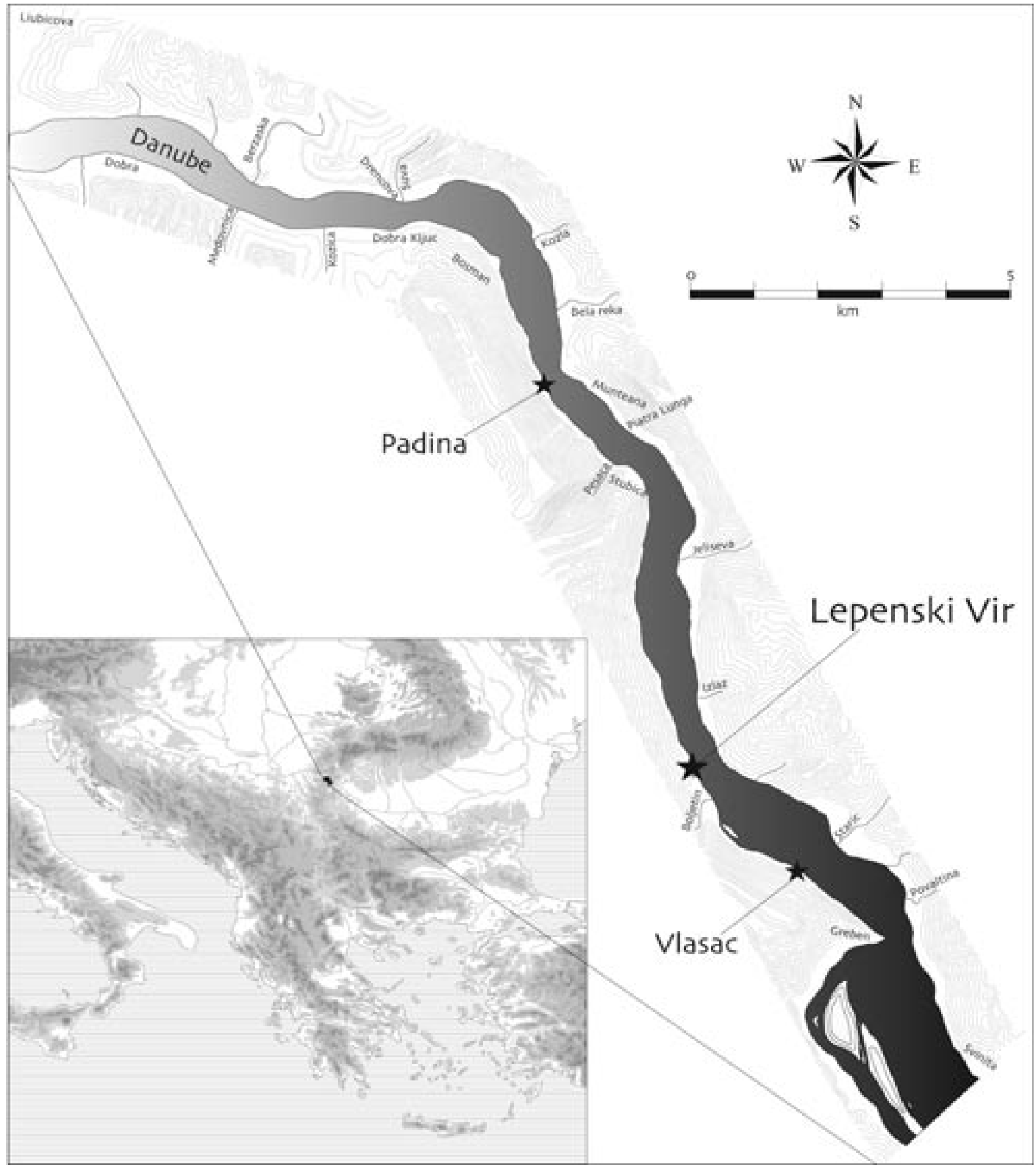

Figure 2. Map showing Meso-Neolithic sites in the Upper Gorge of the Danube.

where a carved boulder replaced the rear narrow end of the stone hearth (Srejović \& Babović 1983, 133). Since a number of boulders and mortars were also found in 'loose' contexts within the settlement deposits in the space between buildings (catalogue numbers $12,20,31,34,35,36,43,60,61 \& 80$ ) or in connection with stone constructions (catalogue numbers 4, 33, 42) (see Table 1; Figs. 3-4), this situation leaves 


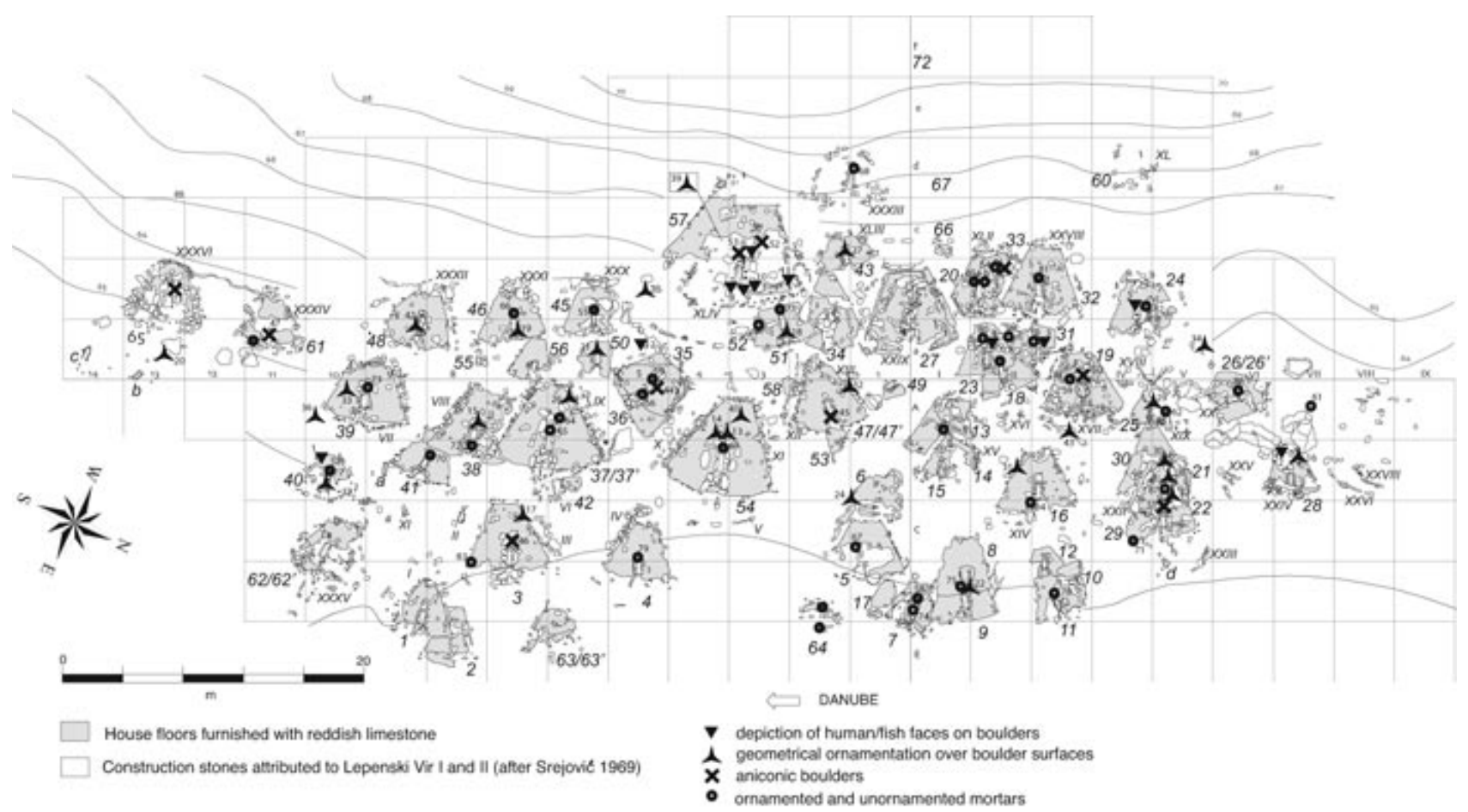

Figure 3. Trapezoidal buildings and construction stones of Lepenski Vir I and II phases according to Srejović (after Srejović 1981, 20-21) with the spatial distribution of boulders and mortars (see Table 1). Large arabic numerals indicate buildings of Lepenski Vir I, small arabic numerals boulders/mortars. Features that the excavator attributed to Lepenski Vir II are marked by roman numerals.

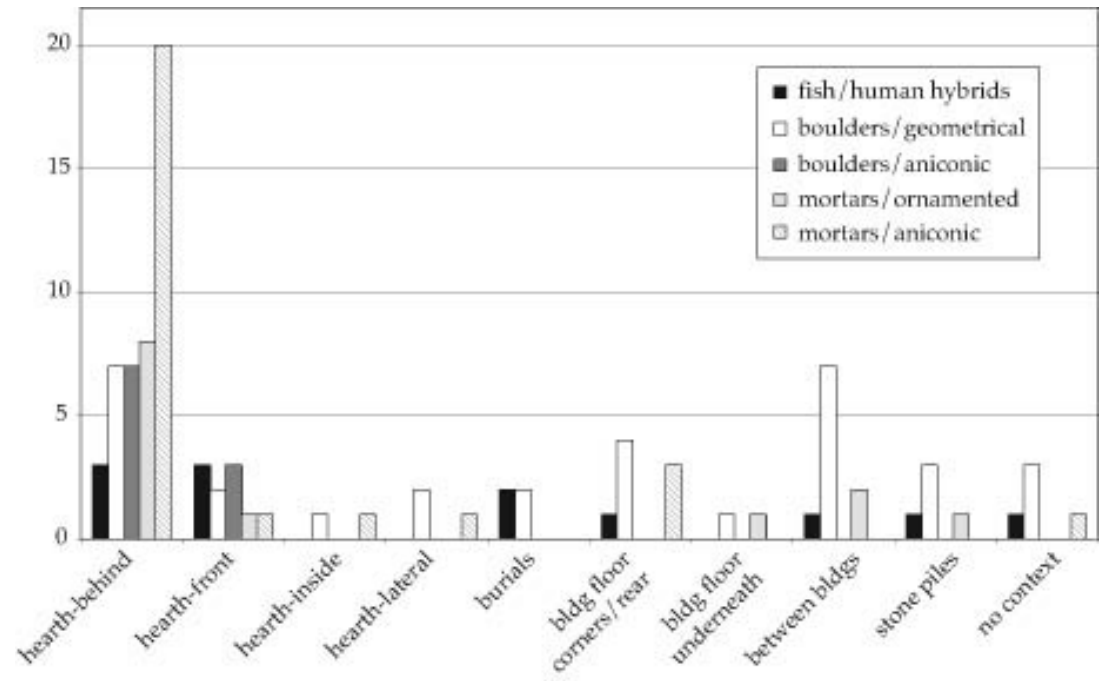

Figure 4. Frequency of spatial association of boulders and mortars at Lepenski Vir (see Table 1).

the possibility that the boulders were moved around and not fixed only to a particular building, notwithstanding their voluminous size (dimensions of the boulders range from 0.9 to $0.62 \mathrm{~m}$ in length and they weigh from $1.1 \mathrm{~kg}$ to over $50 \mathrm{~kg}$ : see Table 1).These instances of boulders found loosely scattered around the settlement, however, represent the secondary context of their use, while their primary association relates to the trapezoidal buildings.

Although we do not yet have absolute dating for each trapezoidal structure from Lepenski Vir, existing radiocarbon dates make it possible to argue that they were largely built and inhabited from $c .6300$ to 5500 cal. BC (Borić 1999; 2002b; Garašanin \& Radovanović 2001). They are thus contemporaneous with the development of the typical Early Neolithic settlements in the surrounding region of the north-central Balkans (Whittle et al. 2002).

On the other hand, just as the elaborate trapezoidal structures at Lepenski Vir and Padina retain in their centre the architectural element of rectangular hearth as a characteristic architectural feature of the preceding regional Mesolithic, so too 
Table 1. Catalogue of ornamented and aniconic boulders and mortars from Lepenski Vir. (Source: Srejović \& Babović 1983; weight: unpublished data, National Museum, Belgrade.)

* Note an error in Srejović \& Babović's $(1983,135)$ catalogue - boulder no. 29 is associated with Burial 4 and not 47.

† Note an error in Srejović \& Babović's (1983, 123, 175), boulder no. 18 and mortar no. 77 are from House 51 and not House 52 (see Srejović 1969, fig. 48).

\begin{tabular}{|c|c|c|c|c|c|c|c|}
\hline No. & House - sculpture name & $\begin{array}{l}\text { Pigment } \\
\text { colour(s) }\end{array}$ & $\begin{array}{l}\text { Colour } \\
\text { intensity }\end{array}$ & $\begin{array}{l}\text { Coloured } \\
\text { (body) part }\end{array}$ & Traces of fire & $\begin{array}{l}\text { Weight } \\
\text { (kg) }\end{array}$ & Context \\
\hline \multicolumn{8}{|c|}{ Ornamented boulders } \\
\hline 1 & H. 28 - Adam [p. 107] & dark brown & $\begin{array}{l}\text { hardly } \\
\text { visible }\end{array}$ & $\begin{array}{l}\text { neck \& } \\
\text { body }\end{array}$ & - & 5.11 & $\begin{array}{l}\text { approx. above child burial } \\
\text { (Burial 92) - rear of build- } \\
\text { ing }\end{array}$ \\
\hline 2 & $\begin{array}{l}\text { H. } 40 \text { - Sirena [Mermaid] } \\
\text { [p. 108] }\end{array}$ & pale red & light & body \& lips & - & 4.26 & $\begin{array}{l}\text { above head of child (Burial } \\
61 \text { ) - rear of building }\end{array}$ \\
\hline 3 & H. 31 - Vrač [Shaman] [p. 109] & red & light & relief parts & - & 8.5 & behind hearth \\
\hline 4 & $\begin{array}{l}\text { H. XXVIII - Hronos [Chronos] } \\
\text { [p. 110] }\end{array}$ & red & $\begin{array}{l}\text { hardly } \\
\text { visible }\end{array}$ & relief parts & present & 21.86 & $\begin{array}{l}\text { stone construction above } \\
\text { House } 23\end{array}$ \\
\hline 5 & H. 24 - Sculpture [p. 111] & - & - & - & $\begin{array}{l}\text { black \& red } \\
\text { on the lower } \\
\text { part }\end{array}$ & 13.6 & behind hearth \\
\hline 6 & $\begin{array}{l}\text { NA - Lady of Lepenski Vir } \\
\text { [p. 112] }\end{array}$ & red & light & $\begin{array}{l}\text { relief parts } \\
\text { of the face }\end{array}$ & - & 5.9 & backfilled earth (1966) \\
\hline 7 & $\begin{array}{l}\text { H. XLIV / } 57 \text { - Rodonačelnik } \\
\text { [Progenitor] [p. 113] }\end{array}$ & red & light & $\begin{array}{l}\text { neck \& eye } \\
\text { holes }\end{array}$ & - & 55 & behind hearth \\
\hline 8 & $\begin{array}{l}\text { H. XLIV / 57 - Praroditeljka } \\
\text { [First Mother] [pp. 114-15] }\end{array}$ & red & light & relief parts & $\begin{array}{l}\text { red on the } \\
\text { back }\end{array}$ & 38.5 & $\begin{array}{l}\text { in front of hearth (lying on } \\
\text { its back) }\end{array}$ \\
\hline 9 & $\begin{array}{l}\text { H. XLIV / } 57 \text { - Danubius } \\
\text { [p. 116] }\end{array}$ & brown-black & $?$ & relief parts & - & 53 & in front of hearth \\
\hline 10 & $\begin{array}{l}\text { H. XLIV / } 57 \text { - Praotac [Great } \\
\text { Grandfather] [p. 117] }\end{array}$ & red & light & $\begin{array}{l}\text { relief parts } \\
\& \text { body }\end{array}$ & $\begin{array}{l}\text { red \& black } \\
\text { on the back }\end{array}$ & 21.25 & in front of hearth \\
\hline 11 & $\begin{array}{l}\text { H. XLIV/57 - Sculpture } \\
\text { [p. 117] }\end{array}$ & - & - & - & - & 10.5 & $\begin{array}{l}\text { NE (B) front corner of } \\
\text { building }\end{array}$ \\
\hline 12 & $\begin{array}{l}\text { NA - Vodena vila [Water } \\
\text { Fairy] [p. 118] }\end{array}$ & red & light & relief parts & - & 23.1 & $\begin{array}{l}\text { space between buildings } \\
\text { - quad. a } / 5\end{array}$ \\
\hline 13 & H. 54 - Black Obelisk [p. 119] & brown-red & light & relief parts & $\begin{array}{l}\text { black whole } \\
\text { upper part }\end{array}$ & c. 50 & behind hearth \\
\hline 14 & H. 54 - Black Obelisk [p. 120] & pale red & patchy & relief parts & $\begin{array}{l}\text { black whole } \\
\text { upper part }\end{array}$ & c. 20 & behind hearth \\
\hline 15 & $\begin{array}{l}\text { H. } 38 \text { - Veliki beleg [Large } \\
\text { Sign] [p. 121] }\end{array}$ & red & light & relief parts & red strip & c. 50 & behind hearth \\
\hline 16 & H. 28 - Sculpture [p. 122] & - & - & - & $\begin{array}{l}\text { the top } \\
\text { - black }\end{array}$ & $?$ & $\begin{array}{l}\text { rear of building - right side } \\
\text { of the stone 'table' }\end{array}$ \\
\hline 17 & H. 3 - Sculpture [p. 122] & - & - & - & black traces & $?$ & $\begin{array}{l}\text { left corner at the back of } \\
\text { the building }\end{array}$ \\
\hline 18 & H. 51† - Vulva [p. 123] & - & - & - & intensive red & 3.2 & in front of hearth \\
\hline 19 & H. 46 - Sculpture [p. 124] & brown-red & light & surface & lower part & $?$ & ash place/in front of hearth \\
\hline 20 & NA - Sculpture [p. 125] & - & - & - & - & 3.4 & $\begin{array}{l}\text { space between buildings } \\
\text { quad. a/13 }\end{array}$ \\
\hline 21 & H. 50 - Sculpture [pp. 126-7] & - & - & - & - & 8.5 & behind the hearth \\
\hline 22 & $\begin{array}{l}\text { H. } 9 \text { - Sculpture } \\
\text { [p. } 128-\text { no. 22] }\end{array}$ & red & light & relief parts & 2 small zones & $?$ & behind the hearth \\
\hline 23 & H. 22 - Vilenjak [Elf] [p. 129] & - & - & - & - & c. 25 & along right side of hearth \\
\hline 24 & $\begin{array}{l}\text { H. } 6 \text { - Stari poglavica } \\
\text { [Old Chief] [p. 130] }\end{array}$ & red & light & relief parts & - & $?$ & next to the building (?) \\
\hline
\end{tabular}


Table 1. (cont.)

\begin{tabular}{|c|c|c|c|c|c|c|c|}
\hline No. & House - sculpture name & $\begin{array}{l}\text { Pigment } \\
\text { colour(s) }\end{array}$ & $\begin{array}{l}\text { Colour } \\
\text { intensity }\end{array}$ & $\begin{array}{l}\text { Coloured } \\
\text { (body) part }\end{array}$ & Traces of fire & & Context \\
\hline 25 & $\begin{array}{l}\text { H. } 21 \text { - Vodena buba [Water } \\
\text { Bug] [p. 131] }\end{array}$ & - & - & - & - & 4.6 & along left side of hearth \\
\hline 26 & H. 37 - Sculpture [p. 132] & red & light & back part & - & 4.7 & in building infill \\
\hline 27 & $\begin{array}{l}\text { H. } 43 \text { - Crvena skulptura [Red } \\
\text { Sculpture] [p. 133] }\end{array}$ & red & intensive & $\begin{array}{l}\text { relief parts } \\
\& \text { strips } \\
\text { extending } \\
\text { ornam. } \\
\text { grooves }\end{array}$ & $\begin{array}{l}\text { decorated } \\
\text { part-inten- } \\
\text { sive }\end{array}$ & $?$ & $\begin{array}{l}\text { taking the role of the rear } \\
\text { stone of the hearth }\end{array}$ \\
\hline 28 & $\begin{array}{l}\text { H. } 71 \text { - Crveni znak [Red } \\
\text { Mark] [p. 134] }\end{array}$ & - & - & - & $\begin{array}{l}\text { across or- } \\
\text { nam. part }\end{array}$ & $?$ & behind hearth \\
\hline 29 & H. 25 - Sculpture [p. 135] & red-brown & light & surface & gray-black(?) & $?$ & above head of Burial $4^{*}$ \\
\hline 30 & H. 21 - Sculpture [p. 136] & red & intensive & relief parts & red & $?$ & on forehead of Burial 7/I \\
\hline 31 & $\begin{array}{l}\text { H. 16 - Beli znak [White Sign] } \\
\text { [p. 137] }\end{array}$ & - & - & - & - & $?$ & next to building (?) \\
\hline 32 & H. 47 - Sculpture [p. 138] & - & - & - & $\begin{array}{l}\text { top - black } \\
\& \text { red }\end{array}$ & 10.6 & left side of building \\
\hline 33 & H. VII - Sculpture [p. 139] & - & - & - & - & $?$ & $\begin{array}{l}\text { infill of House } 39 \text { (quad. } \\
\text { A/10) }\end{array}$ \\
\hline 34 & NA - Larva [p. 140] & - & - & - & - & $?$ & $\begin{array}{l}\text { space between buildings } \\
\text { - quad. a/V }(26 / 7 / 67)\end{array}$ \\
\hline 35 & $\begin{array}{l}\text { NA - Šumski list [Forest Leaf] } \\
\text { [p. 141] }\end{array}$ & red & light & relief parts & - & 1.1 & $\begin{array}{l}\text { space between buildings } \\
\text { - quad. } \mathrm{b} / 5 \text { - disturbed } \\
\text { layer }\end{array}$ \\
\hline 36 & NA - Sculpture [p. 142] & - & - & - & - & $?$ & $\begin{array}{l}\text { space between buildings } \\
\text { - quad. A/10 ( } 7 \text { th exc. layer } \\
\text { to southern section) }\end{array}$ \\
\hline 37 & $\begin{array}{l}\text { NA - Sculpture } \\
\text { [p. 143- no. 37] }\end{array}$ & red & light & relief parts & top - black & $?$ & not in situ (?) \\
\hline 38 & $\begin{array}{l}\text { NA - Medaljon [Broach] } \\
\text { [p. } 144-\text { no. 38] }\end{array}$ & red & very light & $\begin{array}{l}\text { decorated } \\
\text { fringes }\end{array}$ & - & 16.6 & backfilled earth (1966) \\
\hline 39 & $\begin{array}{l}\text { H. XLIV/57 - Sculpture } \\
\text { [p. 145] }\end{array}$ & - & - & - & black (?) & $?$ & beneath floor level \\
\hline 40 & NA - Sculpture [p. 146] & - & - & - & - & $?$ & backfilled earth (1966) \\
\hline 41 & H. 54 - Sculpture [p. 147] & - & - & - & black-gray & $?$ & floor area (?) \\
\hline 42 & $\begin{array}{l}\text { H. XXXIII -Varvarin } \\
\text { [Barbarian] [p. 148] }\end{array}$ & red & intensive & the neck & red & 18.6 & infill of House 48 \\
\hline 43 & $\begin{array}{l}\text { H. XVII - Jelen u šumi [Red } \\
\text { Deer in Forest] [p. 149] }\end{array}$ & red & light & relief parts & - & $50-70$ & in front of House 19 \\
\hline- & H. 40 - Sculpture & $?$ & $?$ & $?$ & $?$ & $?$ & inside hearth \\
\hline \multicolumn{8}{|c|}{ Aniconic boulders } \\
\hline 44 & H. 36 - Aniconic [p. 150] & - & - & - & - & $?$ & behind hearth \\
\hline 45 & H. 47' - Aniconic [p. 150] & - & - & - & - & $?$ & ash place/in front of hearth \\
\hline 46 & H. 3 - Aniconic [p. 151] & - & - & - & - & $?$ & behind hearth \\
\hline 47 & H. 61 - Aniconic [p. 151] & - & - & - & - & $?$ & ash place/in front of hearth \\
\hline 48 & H. 33 - Aniconic [p. 152] & - & - & - & - & $?$ & behind hearth \\
\hline 49 & $\begin{array}{l}\text { H. XXXVI/65 - Aniconic } \\
\text { [p. 152] }\end{array}$ & - & - & - & - & $?$ & behind hearth of House 65 \\
\hline 50 & H. 19 - Čuma [p. 153] & - & - & - & - & $?$ & behind hearth \\
\hline
\end{tabular}


Table 1. (cont.)

\begin{tabular}{|c|c|c|c|c|c|c|c|}
\hline No. & House - sculpture name & $\begin{array}{l}\text { Pigment } \\
\text { colour(s) }\end{array}$ & $\begin{array}{l}\text { Colour } \\
\text { intensity }\end{array}$ & $\begin{array}{l}\text { Coloured } \\
\text { (body) part }\end{array}$ & Traces of fire & & Context \\
\hline 51 & H. 22 - Aniconic [p. 154] & - & - & - & - & $?$ & in front of hearth \\
\hline 52 & $\begin{array}{l}\text { H. XLIV / } 57 \text { - Aniconic } \\
\text { [p. 155] }\end{array}$ & - & - & - & - & $?$ & behind hearth \\
\hline 53 & $\begin{array}{l}\text { H. XLIV / } 57 \text { - Aniconic } \\
\text { [p. 155] }\end{array}$ & - & - & - & - & $?$ & behind hearth \\
\hline \multicolumn{8}{|c|}{ Ornamented mortars } \\
\hline 54 & $\begin{array}{l}\text { H. } 33 \text { - Jelen [Red Deer] } \\
\text { [p. 158] }\end{array}$ & red-brown & $?$ & $\begin{array}{l}\text { non-orna- } \\
\text { ment. part }\end{array}$ & - & 5.85 & behind hearth \\
\hline 55 & H. 45 - Riba [Fish] [p. 159] & - & - & - & burned head & 6.4 & behind hearth \\
\hline 56 & H. 35 - Mortar [p. 160] & - & - & - & - & $?$ & ash place/in front of hearth \\
\hline 57 & H. 40 - Mortar [p. 161] & red-brown & intensive & relief parts & - & 3.7 & behind hearth \\
\hline 58 & H. 7 - Mortar [p. 162] & - & - & - & - & 6.6 & behind hearth \\
\hline 59 & H. 19 - Mortar [p. 163] & - & - & - & - & $?$ & beneath floor \\
\hline 60 & NA - Mortar [p. 164] & red-brown & $?$ & relief parts & - & $?$ & $\begin{array}{l}\text { space between buildings } \\
\text { - quad. a/ II }(24 / 7 / 67)\end{array}$ \\
\hline 61 & NA - Mortar [p. 165] & - & - & - & - & $?$ & $\begin{array}{l}\text { space between buildings } \\
\text { - quad. A/VII }(24 / 7 / 67)\end{array}$ \\
\hline 62 & H. XIX - Mortar [p. 166] & - & - & - & - & 1.5 & behind hearth \\
\hline 63 & H. 54 - Mortar [p. 167] & - & - & - & - & $?$ & behind hearth \\
\hline 64 & H. 37 - Mortar [p. 168] & - & - & - & $\begin{array}{l}\text { red - rim of } \\
\text { the recep- } \\
\text { tacle }\end{array}$ & 14.6 & behind hearth \\
\hline 65 & H. 37 - Mortar [p. 169] & red-brown & $?$ & $\begin{array}{l}\text { buried por- } \\
\text { tion-relief } \\
\text { parts }\end{array}$ & - & 48.95 & $\begin{array}{l}\text { behind hearth - lower por- } \\
\text { tion buried in floor }\end{array}$ \\
\hline 67 & H. 5 - Mortar [p. 171] & - & - & - & $\begin{array}{l}\text { burned } \\
\text { surface }\end{array}$ & $?$ & $\begin{array}{l}\text { from pile of stones within } \\
\text { building(?) }\end{array}$ \\
\hline \multicolumn{8}{|c|}{ Aniconic mortars } \\
\hline 66 & H. 46 - Mortar [p. 170] & - & - & - & $\begin{array}{l}\text { burned on } \\
\text { the upper } \\
\text { surface }\end{array}$ & $?$ & behind hearth \\
\hline 68 & H. XXXIII - Mortar [p. 172] & - & - & - & - & 28.9 & behind hearth \\
\hline 69 & H. 36 - Mortar [p. 173] & - & - & - & - & $?$ & behind hearth \\
\hline 70 & H. 41 - Mortar [p. 173] & - & - & - & - & $?$ & behind hearth \\
\hline 71 & H. 29 - Mortar [p. 173] & - & - & - & - & $?$ & front left corner of building \\
\hline 72 & H. 38 - Mortar [p. 174] & - & - & - & - & $?$ & ash place/in front of hearth \\
\hline 73 & H. 39 - Mortar [p. 174] & - & - & - & - & $?$ & behind hearth \\
\hline 74 & H. 7 - Mortar [p. 175] & - & - & - & - & $?$ & within hearth \\
\hline 75 & H. 9 - Mortar [p. 175] & - & - & - & - & $?$ & behind hearth \\
\hline 76 & H. 31 - Mortar [p. 175] & - & - & - & - & $?$ & behind hearth \\
\hline 77 & H. 51† - Mortar [p. 175] & - & - & - & - & $?$ & behind hearth \\
\hline 78 & H. 11 - Mortar [p. 174] & - & - & - & - & $?$ & behind hearth \\
\hline 79 & H. 4 - Mortar [p. 175] & - & - & - & - & $?$ & behind hearth \\
\hline 80 & H. 23 - Mortar [p. 176] & - & - & - & - & $?$ & behind hearth \\
\hline 81 & H. 32 - Mortar [p. 177] & - & - & - & - & $?$ & behind hearth \\
\hline
\end{tabular}


Table 1. (cont.)

\begin{tabular}{|c|c|c|c|c|c|c|c|}
\hline No. & House - sculpture name & $\begin{array}{l}\text { Pigment } \\
\text { colour(s) }\end{array}$ & $\begin{array}{l}\text { Colour } \\
\text { intensity }\end{array}$ & $\begin{array}{l}\text { Coloured } \\
\text { (body) part }\end{array}$ & Traces of fire & & Context \\
\hline 82 & H. 24 - Mortar [p. 177] & - & - & - & - & $?$ & behind hearth \\
\hline 83 & H. 3 - Mortar [p. 178] & - & - & - & - & $?$ & front corner of building \\
\hline 84 & H. XIV - Mortar [p. 178] & - & - & - & - & $?$ & $\begin{array}{l}\text { behind hearth [above the } \\
\text { level of House 16] }\end{array}$ \\
\hline $85 a$ & H. 20 - Mortar [p. 179] & - & - & - & - & ? & behind left corner of hearth \\
\hline $85 b$ & H. 20 - Mortar [p. 179] & - & - & - & - & $?$ & $\begin{array}{l}\text { behind right corner of } \\
\text { hearth }\end{array}$ \\
\hline 86 & H. 26' - Mortar [p. 179] & - & - & - & - & ? & on left side of hearth \\
\hline 87 & H. 22 - Mortar [p. 180] & - & - & - & - & 5 & behind hearth \\
\hline 88 & NA - Mortar [?] [p. 181] & - & - & - & - & $?$ & not in situ (?) \\
\hline- & H. 13 - Mortar & $?$ & $?$ & $?$ & $?$ & $?$ & behind hearth \\
\hline- & H. 18 - Mortar & $?$ & $?$ & $?$ & $?$ & ? & behind hearth \\
\hline- & H. 64 - Mortar & $?$ & $?$ & $?$ & $?$ & $?$ & back of building \\
\hline - & H. 64 - Mortar & ? & $?$ & ? & $?$ & $?$ & behind hearth \\
\hline
\end{tabular}

the tradition of boulder artworks has its roots in the preceding Epi-Palaeolithic and Mesolithic traditions of engraving on bone, antler, and tusk as well as stone (e.g. Boroneanţ 1970; 2001; Srejović \& Letica 1978; Srejović \& Babović 1983; Păunescu 1970). The tradition of boulder artworks is, thus, both the continuation of earlier forms of visual expression and a newly-emergent field of production, possibly starting around 6300 cal. вс. This might have addressed historicallychanged constellations of social, cultural, ideological and / or religious forms, or have been related to identity-formation, embodying varying degrees of social efficacy until the final abandonment of settlements in this region around $5500 \mathrm{cal}$. BC.

Relating boulders to the architectural stratigraphy and phasing of Lepenski Vir, the excavator of the site, Srejović, suggested a scheme that defines stages in the stylistic development of boulder artworks (1969, fig. 29; 1972). More recently, Radovanović has re-phased trapezoidal structures at this site and consequently suggested a different scheme for the stylistic development of sculpted boulders (1996, fig. 3.62). However, both of these stratigraphic, and ultimately stylistic, schemes may be flawed on factual grounds due to the necessary radical revision of the site's stratigraphy (Borić 2002b,c). It would hence be wise to obtain a secure absolute dating for the chronological range of occupation of particular buildings before attempting further phasing of buildings and associated boulders. Moreover, there is evidence that boulders might have been moved from buildings that were abandoned and inserted at new locations. This is indicated in a number of instances by empty sockets (9-20 cm wide) found in the floors of some buildings to the rear of hearths (e.g. Houses 1, 4, 16, 26, 27, 35, 37, 47), which may have held boulders (Srejović 1969, 95). It also seems that in some instances smaller parts of larger boulders were inserted, such as in House 9 (Srejović 1969, 114). This possibility further complicates our ability to phase the encountered variety of modified and unmodified boulders and mortars on the basis of their contextual position.

We may suggest that we observe some contextual patterning assuming that in a number of instances boulders remained fixed to their 'original' location after a building was abandoned. For instance, some aniconic boulders could chronologically represent the first form of 'artwork', before any designs were applied over boulders' surfaces (Srejović 1969, 106). ${ }^{3}$ Several buildings are associated exclusively with aniconic boulders or mortars at Lepenski Vir - neighbouring Houses 61 and 65 in the southwestern part of the settlement, and House $47^{\prime}$. These buildings might have been among the earliest structures at the site, judging from the mortuary rites of associated burials in House 65 and the stratigraphic position of House $47^{\prime}$ (Fig. 3).

On the other hand, other buildings that also might have been among the earliest trapezoidal structures at the site (e.g. Houses 62', 62, 63', 63, 27, 34,56 , etc.) have no associated boulders or mortars. This may be both the consequence of the lack(ing significance) of the boulder tradition during the occupation of these buildings as well as the possibility 


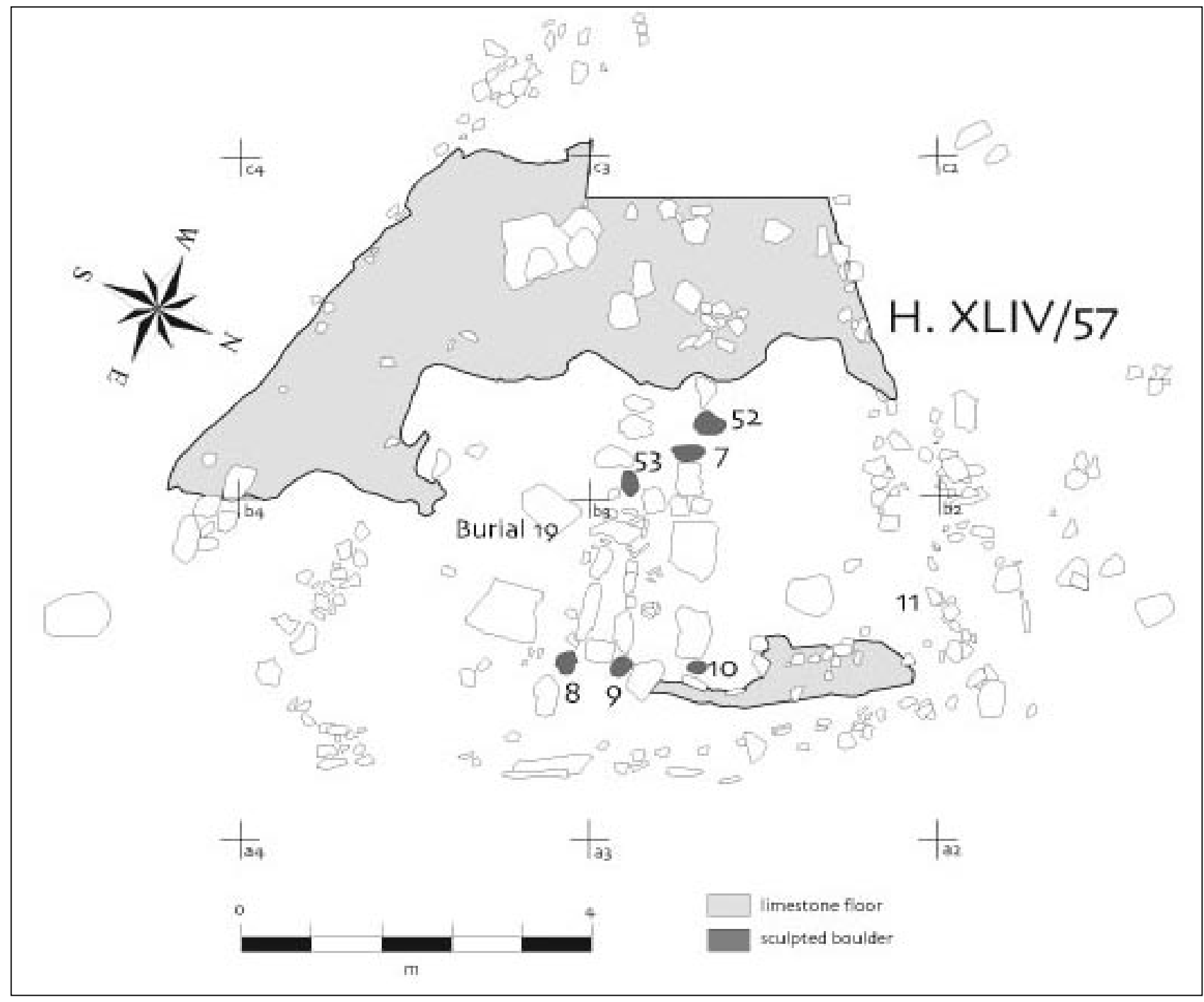

Figure 5. House XLIV/57 has the largest concentration of boulders at Lepenski Vir.

already mentioned that boulders were moved from their initial locations. Following this logic, one could suggest that the building that accumulated the largest number of boulder artworks (almost exclusively representational or figural) House 57/XLIV (Fig. 5), was among the last buildings to be occupied before the effective abandonment of the site. These remarks remain tentative until new AMS dates are obtained.

Figure 6 quantifies relevant elements of building complexity (boulders, mortars, variety of burials, A-supports) in order to examine the complexity of building associations and inter-building variability at Lepenski Vir. This assumes that the presence/absence of these elements may have some significance in the 'final status' of each building. No obvious patterning can be discerned and the variety in the quantity of elements would reaffirm the idea that what we witness here are traces of very individualized histories for each building (and its inhabitants), where the prescribed 'ideal' lifecycle of a building (and an individual) always remains incomplete, unrealized and unrealizable (cf. Gell 1998; see below).

Placed on the floors of trapezoidal buildings, boulders as well as ornamented and unornamented mortars were primarily found occupying a designated space at the rear side on the hearth, although in a number of instances boulders were also found associated with burials (Burials 7/I-a, 4, 61 and 92, see Fig. 7), in corners or at the rear of buildings (Houses $3,6,28,29$ ), under building floors (House XLIV / 57) or on the front of their rectangular hearths (Houses XLIV/57, 51, 22, 47', 46, 61) (see Table 1; Figs. 3-4). These spatial patterns will be discussed further below with regard to a possibly significant relationship 


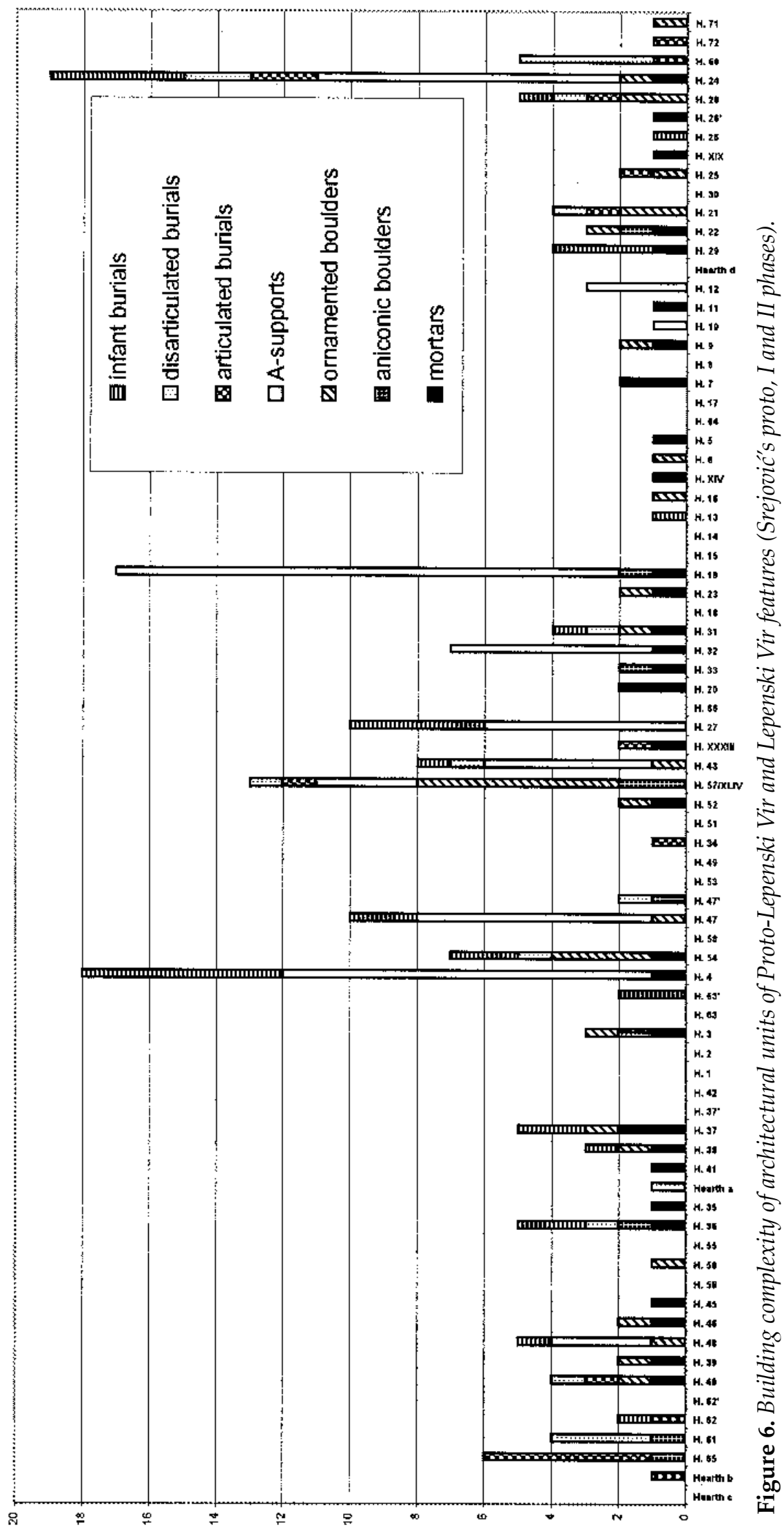

between some representationally-engendered boulders and the social mapping of building space in gendered terms. Building on the initial remark about the boulder's body-like character, I shall later indicate the salience of their spatial associations in relation to the articulated and disarticulated human burials found in trapezoidal buildings.

\section{Interpreting art}

Although the boulder artworks from Lepenski Vir have been the focus of attention since their discovery, there has been little discussion about these artworks from an anthropological perspective as opposed to previous, largely art-historical accounts preoccupied with the aesthetic qualities of carved boulders. The boulder artworks from Lepenski Vir have been singled out by the excavator of the site, Dragoslav Srejović $(1969 ; 1972)$, as the first monumental sculpture of Europe, drawing on the modernist and Western myth about an originary cultural tradition and the "birth of art'. Srejović's account points out the value of these artworks as one of the decisive 'missing links' in the progressive development towards civilization. This quest for a 'pure' and originary European culture endowed with 'truly' artistic features comes from a specific discursive and socio-political formation that can be related to Orientalism (cf. Turner 2001; Borić in press a). Furthermore, one needs to take a critical stance with regard to Srejović's approach to boulder artworks since, as Handsman argues, this approach rests on 'the tacit agreed-upon assumption that aesthetic achievement and the competence to identify it are universally shared and timeless' 


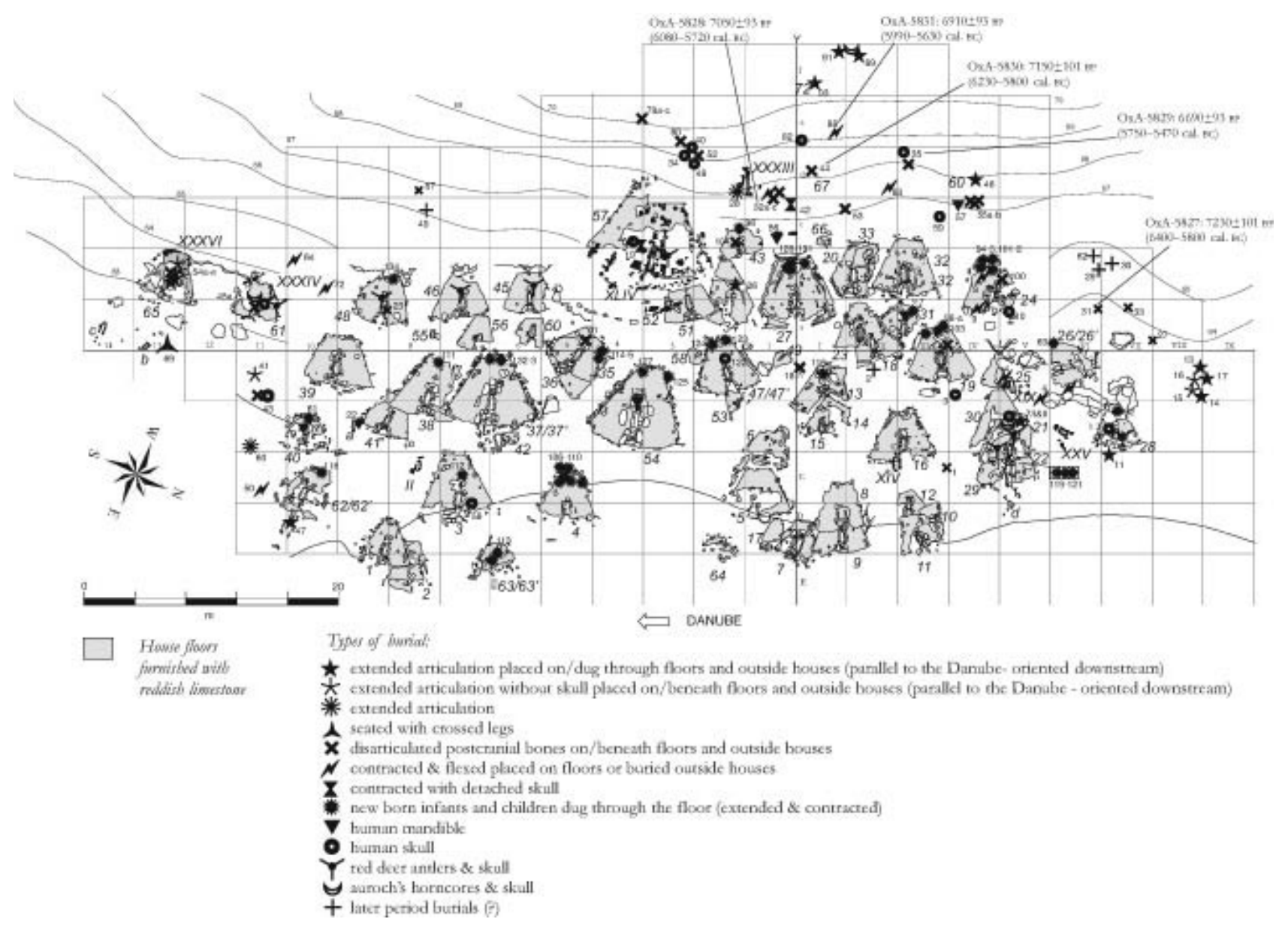

Figure 7. Trapezoidal buildings and construction stones of Lepenski Vir I phase according to Srejović (after Srejović 1981,20-21) and types of burial on/beneath building floors and outside buildings from all phases. Large arabic numerals indicate buildings of Lepenski Vir I, small arabic numerals burials, all phases. Some features of Lepenski Vir II are also shown here and marked by roman numerals.

(1991, 332). In addition, as Chapman explains, the excavator's habit of giving modern names to individual boulders (Progenitor, Adam, Grandfather, etc.; see Table 1) 'distract[s] from the special mystery of the boulders which can never be penetrated by metaphor of naming' (1993, 95). Yet, as I show below, it is possible to rescue certain aspects of Srejović's inspiring ethnography of these artworks (cf. Whittle 1998).

Another prominent perspective has been that of Marija Gimbutas (1982; 1991). Gimbutas characterized the representational boulders as important examples of the Mother Goddess tradition. This account has a strong New Age pretext (Meskell 1995). Gimbutas relies on a nostalgic assumption about the Neolithic of 'Old Europe' as a lost matriarchal paradise before the arrival of Indo-European horse-riding warriors with the start of the Copper Age.

Most of the authors that have discussed the boul- der artworks from Lepenski Vir more recently have focused on their significance as a specific expression of an ideological framework that characterizes a 'typical' Mesolithic fisher-hunter-gather society as opposed to a 'typical' Early Neolithic farmer society.

Radovanović, for instance, suggests that this artistic tradition in the Danube Gorges, and specifically at Lepenski Vir, might have been a part of an ideological resistance to surrounding farming groups, wherein the community in the Gorges searched for an integrative principle by expressing its cultural identity through particular ornamentation and the proliferation of sculpted boulders, elaborating on the beliefs of the Mesolithic fishermen, most clearly voiced at the central place of this culture group, i.e. at Lepenski Vir (1997). Radovanović puts forward a novel approach toward this art tradition, examining elements such as their representational features, the orientation of 
human burials and the significance of migratory fish in the Danube in order to offer an alternative interpretation. The discussion which follows here will partly draw from her argument. Yet, I shall largely divest myself from the part of Radovanović's argument that emphasizes the role of the boulder artworks in the ideological unification of the community of the Danube Gorges, with an underlying resistance theme (cf. Borić in press a,b). Instead of this functionalist argument I shall focus more on boulder artworks as a way to conceptualize some salient cognitive, social and gender principles that operated in this community.

Chapman has recently suggested that at Lepenski Vir one may distinguish two groups - fish-eaters and meat-eaters - who might have coexisted in two separated lineages as a consequence of contacts with the surrounding farming communities (2000). This author asserts that the 'final transformation' of this 'segregated' community into 'pure' farmers took place with 'the abandonment of the sculptural tradition' (1993, $115 ; 2000)$. Chapman does not exclude the possibility of both internal and internal-external social crises in this society, which might have given the impetus behind the appearance of such artistic expressions.

The main problem of both quoted accounts, however, is the essentialist separation of foragers and farmers as a way of simplifying the construction of Mesolithic vs. Early Neolithic identities primarily on the basis of subsistence resources (Borić 2002b, $1036-8$; in press $a, b)$. One is left to wonder how easily can we separate the two, and how different in reality were the beliefs of the 'foragers' of the Danube Gorges as opposed to the contemporaneous 'farmers' in the Morava, middle Danube and Tisza valleys of the north-central Balkans (cf. Whittle 1998; Borić 1999).

In another account, characterized by a discourse of second wave feminism, Handsman (1991) suggests that within this community of 'complex hunter-gatherers' in the Danube Gorges, women might have achieved an expression of their suppressed role in the society through art. Handsman's account is heavily based on the Marxist discourse of social inequalities and control, conflating possible lineage struggles with the notion of class struggles. It is not quite clear how he comes to conclude that some ornamental motifs found on boulders were 'symbols of some women's independence and their power to challenge an emerging elite' of younger males (Handsman 1991, 357).

Furthermore, in all the foregoing accounts, the interpretations of boulder artworks have been heavily influenced by Srejović's original view that envisions the duality of spatial relations and subsequent duality of social orders at Lepenski Vir (also Hodder
1990; Radovanović 1996; 2000). On the one hand, it is problematic to rely on Srejovićs phasing of Lepenski Vir owing to the necessary revision of stratigraphic relations at this site (cf. Borić 1999; 2002b; Garašanin \& Radovanović 2001), which makes the continuous use of Srejović's phases dubious. On the other hand, an unquestioned assumption about the symmetrical relationship between spatial and social orders is a further problematic aspect of this type of argument.

In a recent account, it was suggested that the boulders represented 'river gods' that might have had an 'apotropaic' role against assumed major floods by the Danube between 6300 and 5950 cal. BC (Bonsall et al. 2002; see also Chapman 1993, 107). Criticism of certain logical incongruities in this argument, with regard to the available evidence of flooding and temporal discontinuity of Meso-Neolithic occupations in this region, has, however, been expressed (cf. Borić \& Miracle 2004). Unfortunately, Bonsall et al. (2002) provide no in-depth discussion of the character of this possible 'apotropaic' role.

This artistic tradition has also been seen as a direct and literal representation, i.e. translation, of everyday reality and natural features of the area on various media of artistic expression as suggested by Marshack (1981, cited by Chapman 1993, 95-6), for instance, referring to 'water-related images' present in many Eurasian societies at the end of the last Glacial period.

Following Ingold (2000b), I would emphasize that it could be problematic to understand the art of traditional societies by applying our representationlist assumptions. These are the outcome of Western modernity and characterized by the implicit notion of progress, possibly remote from what 'artistic' depictions signify or do in non-Western and pre-modern social contexts. This view was most clearly expressed by Alfred Gell's important project for an anthropological approach to the study of art (1998), to which we will now turn.

\section{Aesthetic allure and social efficacy of artworks}

The view that the classic aesthetic approach of art history is hardly sufficient for anthropological or archaeological attempts to study the art of traditional societies or the art of past societies has recently been voiced (e.g. Gell 1996; 1998; see also Pinney \& Thomas 2001). What is lacking in aesthetic approaches to 'primitive' art, Gell argues, is an understanding that art objects constitute a network of relationships that is primarily social. The first point that Gell makes is that art objects interact between themselves as a co- 
herent stylistic system via mediating human agency, while themselves becoming part of a social network. Gell admits the Maussian legacy in emphasizing that art objects (but also other objects) are extensions of complex webs of personhoods surrounding their production, distribution and narrative refiguring. Or as Ingold puts it, speaking of the ontology of the Ojibwa hunters and trappers of Canada, '[a]nimacy [...] is a property not of stones as such, but of their positioning within a relational field which includes persons as foci of power' where 'life is not a property of objects at all, but a condition of being' (2000a, 97, original emphasis). Moving on from this first 'amendment' to an anthropological study of primarily non-Western art, Gell (1998) concludes that from an anthropological point of view artworks (both decorative and 'representational') are primarily about their effectiveness, i.e. about doing and not representing (cf. Küchler 2002).

Hence the aesthetics of artworks need to be understood as being a function of their social potency (cf. Gosden 2001). Yet, one may ask, how do we distinguish art objects from other 'things?' A possible answer is hinted at in Gell's essay 'Vogel's Net: Traps as Artworks and Artworks as Traps' (1996), where a cross-cultural metaphor of capture and containment related to traps (seen as a Faustian trope) is compared to a similar captivation that artworks can inflict, blurring the difference between objects of art sensu stricto and types of complex, cunning traps or snares. Yet Gell refutes the notion that every object can be considered an artwork and asserts that the term 'artwork' should be restricted to those objects that embody 'complex intentionalities'. Hence, according to Gell, the allure and virtuous execution of complex patterns in geometric and ornamental art in general can literally be seen in the function of 'trapping' and confusing the onlooker caught in a 'mind-trap', sometimes achieving an important apotropaic role, acting as 'demon-traps' (1998, 73-95).

Two concepts from Gell are taken as important points in my analysis of the social function of boulder artworks from Lepenski Vir; first, that artworks embodying complex intentionalities have a social, relational agency and that accordingly we need to understand them as powerful works; and second, the radical rejection of the idea that geometric and ornamental art are about aesthetic pleasure.

In a most general sense the collection of artworks from Lepenski Vir can be understood as sacred heirlooms of particular trapezoidal buildings, i.e. 'houses', if these structures are seen as embodiments of various levels of social unit, such as nuclear family, lineage, clan, etc. (cf. Carsten \& Hugh-Jones 1995; Joyce \&

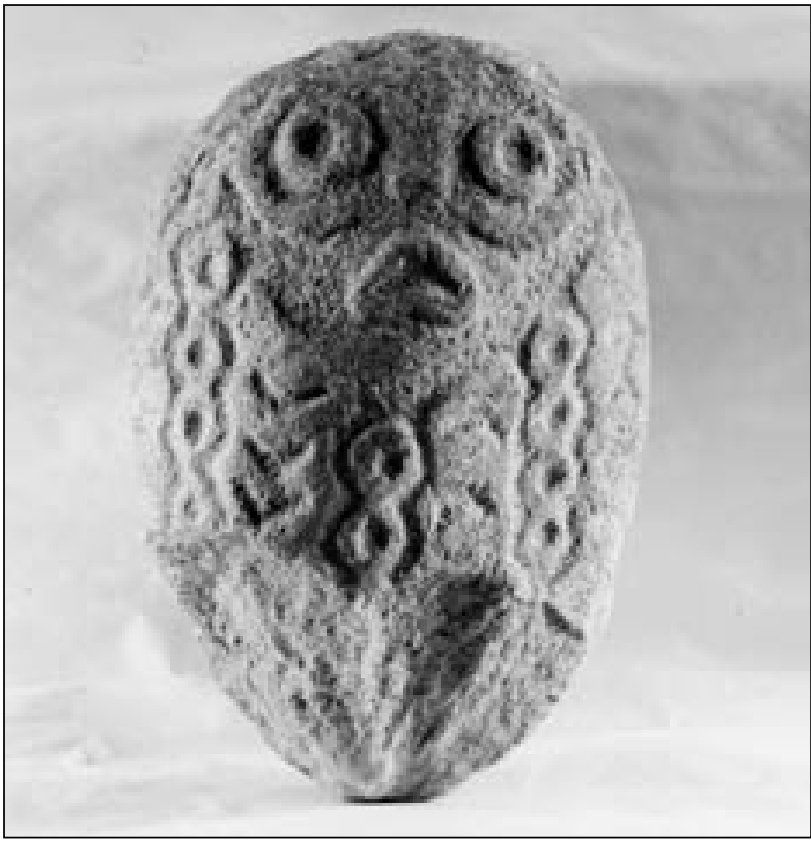

Figure 8. Boulder 'Water Fairy' (no. 12) found between buildings in quad. a/5 (Srejović \& Babović 1983, 118; see Fig. 5).

Gillespie 2000). If understood as sacred heirlooms, the boulders might have been memory foci for the inhabitants of a house but also of the whole community. I have previously emphasized that these boulders although frequently found fixed in relation to a building's hearth were likely moved within a building, around the settlement and possibly beyond, just as were the disarticulated body parts of the deceased found in settlement deposits from this and other neighbouring sites. Moreover, both representational and non-representational boulders commemorated particular individuals, and this situation importantly connects boulders with the realm of the dead and ancestors, i.e. they could be seen as bridging the world of the living and that of the dead. This connection between the body of the deceased and boulders is further reaffirmed in those instances where boulders explicitly depict human-fish hybrids (Fig. 8).

Srejović himself $(1969 ; 1972)$ points out the spherical surfaces and closeness of boulder forms, hinting at the omphalos-like qualities or meanings that might have been attributed to these objects. His stylistic analysis and interpretation of the artistic tradition from Lepenski Vir, although highly charged with the art-historical approach, brings to fruition a number of salient points for an anthropological inquiry. He emphasizes the boulders' body-like character and suggests that any modification of the boulders was 


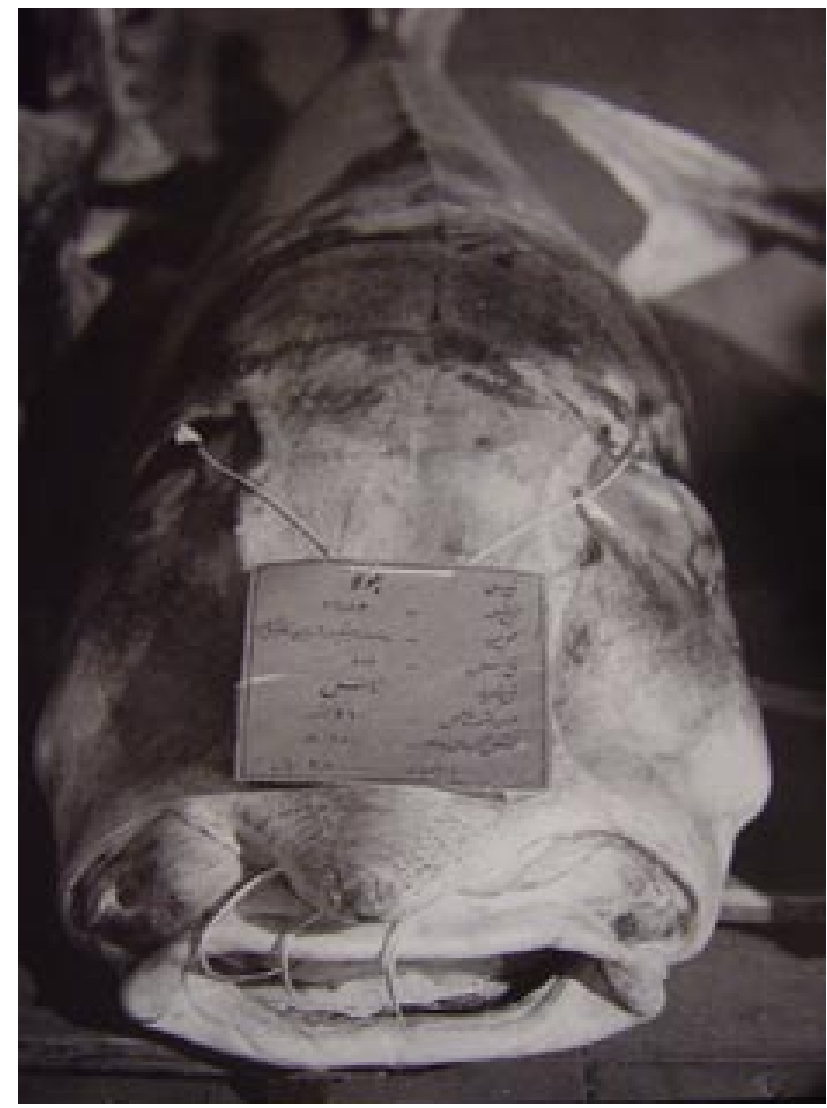

Figure 9. Beluga Huso huso (after Boeckmann $\mathcal{E}$ Rebeiz-Nielsen 1999, 28).

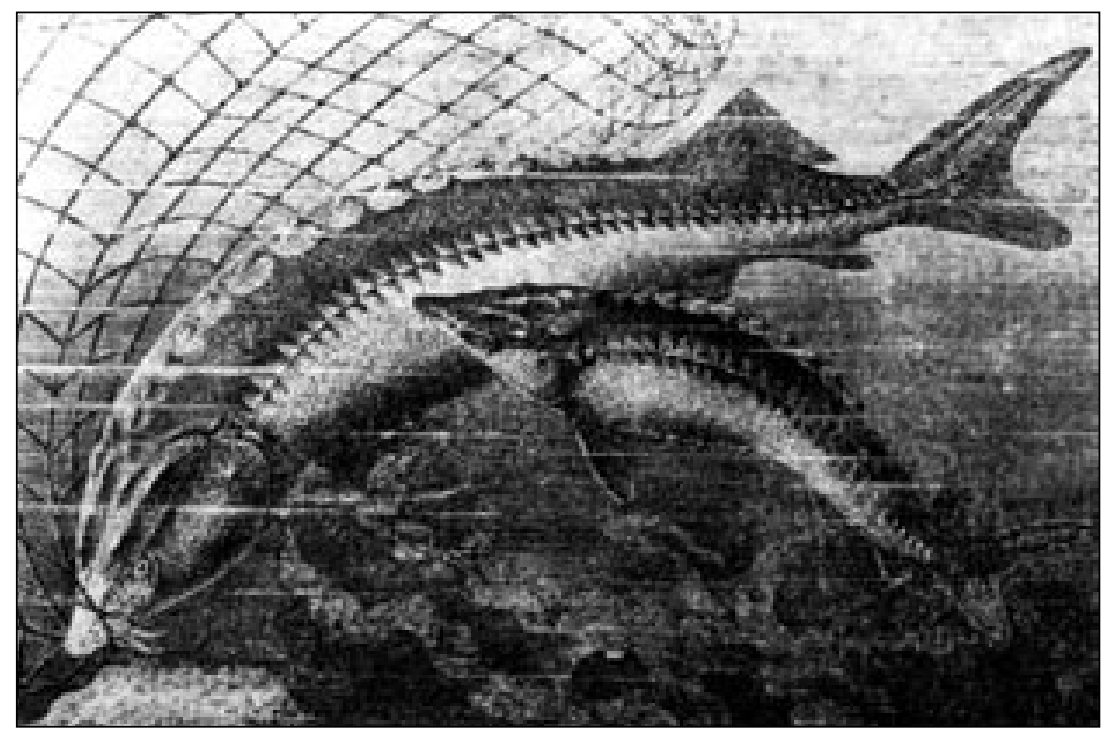

Figure 10. Sturgeon caught in fisherman's net (after Petrović 1941). as if these ornaments came from the interior of the boulder itself. This remark might apply more closely to decorative modifications, but it is also relevant to 'naturalistic' depictions where the form of a hybrid being emerges from the boulder (e.g. Fig. 8). In this way, the representation has no depth and turns into a perfect seamless surface, which envelopes the boulder form. The executed ornament is a projection of the interior onto the surface. Even with the so-called X-ray instances of the depiction of interior body organs on some boulders, these organs are part of the surfaces. Srejović does not acknowledge the resemblances of boulders and fish, but rather stresses a wider range of natural inspirations for the diversity of decorations and representations, indicating that, for instance, the large downturned mouth depicted on some boulders relates to the expression of an inner emotional state rather than resembling fish $(1969,122)$.

Yet it is hard to deny the fish-like qualities of these boulders. For the sake of the present discussion, some fish and human features that occur on boulders should be identified. The most prominent, and often the only, body part represented on boulders is the head, i.e. the face. The most characteristic fish feature on most of the representational boulders is the downturned mouth. Furthermore, the face represented, with two exceptions, appears on the boulder surface without a neck, which would also be typical for the depiction of a fish being, as is the rounded form of the rest of the body. On the other hand, instead of placing the eyes on the sides and giving a pointed snout - features that characterize fish, and sturgeon in particular - the layout of the eyes and the nose is very similar to the human face, i.e. these features are represented frontally. Since sturgeon, and particularly the largest fish in this family, beluga Huso huso, are characterized by visible bony scales and very large downturned mouth (Figs. 9 \& 10) it would be reasonable to assume that at least those representational boulders with such attributes, if not all, depict sturgeon. Only one boulder more explicitly depicts a human torso, showing two arms and a vulva (Fig. 11).

Srejović suggests that his impression of boulder surfaces is that of volatile and metamorphizing body forms $(1969 ; 1972)$. A possible connection between the dead body of the deceased and boulders is of relevance here, and one 
may make an assumption that boulders in their close affinity with dead bodies objectify the transformational character of the body matter and its change through time, in the same way in which the human and animal identities are transcended and changed by the movement of the corporeal matter through life and death in the processes of becoming. Such an assumption poses the question of bodily change as central for understanding the impulse behind the hybrid being depictions on boulder artworks from Lepenski Vir.

While current body theory and its influence on archaeology are primarily restricted to social constructivism and gendered or performative

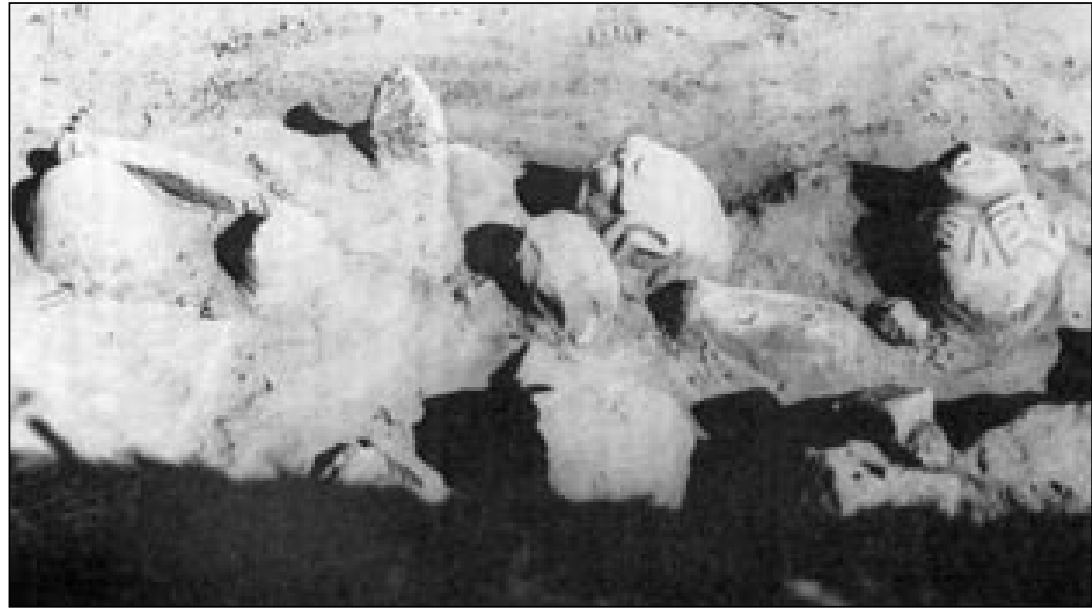

Figure 11. Sculpted boulders 'Danubius' (no. 9) and 'First Mother' (no. 8) in front of the hearth of House XLIV/57, Lepenski Vir (after Radovanović 1996, fig. 3.61). identities (e.g. Yates \& Nordbladh 1990; Yates 1993; Joyce 1996; Meskell 1999), the phenomenon of body change and processuality of the body matter and identity, as they might have been understood by humans at various times in the past, are hardly discussed (but see Yates 1990, 187-97). At stake here is the formidable threat to the continuity of one's identity through time given the perpetual state of becoming of corporeal matter (Bynum 1995; 2001). The under-theorization of this issue characterizes the wider field of social theory that focuses on the body, and in order to examine this lack of theoretical focus and theorize the question of bodily change I explicitly turn to the field of body studies.

\section{Body theory: subjectification and performativity}

The term 'body theory' refers to the field of research that in the last couple of decades made the body one of the central theoretical topics of sociological, philosophical and anthropological debates, strongly influencing certain strands of research in related disciplines, including archaeology. In this way, these fields of study through the newly-chosen focal point - the body, serving as a sort of theoretical proxy - readdressed and recharged much older themes and debates, such as materialism, essentialism, subjectivity and self-identity, social basis of behaviour, ideology, social inequalities, and sex/gender differences. Yet, this peculiar discovery of the body by social theory in particular can closely be related to the wider cultural and political context of the present-day, described by some authors as late capitalist consumer society (Featherstone 1990; 1991) or high modernity (Giddens
1990). Thus, the increasing individualism of presentday culture is centred around the body, as a primary signifier, with its resultant commodification through the capitalist mode of production. Moreover, this reemergence of the body and its long 'present absence' - 'present as an item for discussion, but absent as an object of investigation' (Shilling 1993) - in sociological debates can importantly be related to the realization of a long separation in treating physical and corporeal on one hand and social agency on the other hand by separate disciplinary realms. It has further been suggested that the founding figures of sociology frequently left the body and the issue of its materiality to the realm of the natural sciences (Shilling 1993, 24-5; Turner 1991). This dichotomous and polarized shadow of the Cartesian separation of mind and matter has also systematically haunted the newly emerging field of body theory.

In this context, over the past two decades naturalistic and social constructivist views of the body became two main strands of thought. For naturalistic views in social theory the body itself 'gives rise to particular patterns of social relations' without acknowledging that 'these [social] relationships themselves impinge upon the shape and development of bodies' (Shilling 1993, 67). On the other hand, the social constructivist approach is most importantly represented in its different forms by influential figures such as Michel Foucault and Mary Douglas, understanding and reducing the body to social categories that shape and produce the body. For Foucault, the body is 'produced by and existing in discourse' (Shilling 1993, 75), envisioning a panopticist matrix of infra-conscious control over individual perceptions and thoughts, where the 
body is always already 'culturally mapped; it never exists in a pure or uncoded state' (Fuss 1990, 6).

Consequently, there have been attempts to transcend and overcome these naturalist and discursive essentialisms by stressing the unfinishedness of the body at birth (Turner 1992), the phenomenology of embodiment and lived experience (Turner 1984; cf. Merleau-Ponty 1962), processes of subjectification (Giddens 1991) and the need to take the coroporeality of the body seriously (Shilling 1993, passim). There has also been emphasis on the ways that attitudes toward the body changed historically, with important differences in how embodied individuals lived their lives in particular historical and social contexts (e.g. Elias 1994; Bynum 1995). In this latter area of research, in particular, archaeology is making its contribution with an explicit reference to the wider field of body studies (e.g. Treherne 1995; Meskell 1996; 1998; 1999).

In archaeology too, the social constructionists' perspective on the body has figured prominently. One example relevant for Lepenski Vir can illustrate the point. In the Domestication of Europe, Hodder (1990, 25) indicates that death dominates houses of Lepenski Vir. In his opinion, at this site, as at Çatalhöyük, 'the domestication of the death' takes place by bringing the dead body into the house (Hodder 1990, 29). The power discourse is evoked in this interpretation, seeing the direct control exercised over the dead body, being controlled and acted upon. In this account, the body serves as a passive tool for control over the society at large. The body is merely a means for the playingout of larger structures that deliver fixed meanings. As Meskell argued in her critique of the social constructionists' view of the body, this is both 'the body as artefact' and 'the body as the scene of display' (1996, 6-7). Meskell suggests that archaeological inquiries into lived and experienced bodies should escape the discourse of domination and control (Meskell 1996, 9). One could argue that the body in social and cultural contexts (re)produces shared meanings through dialectic and mimetic processes. Bodies would thus be seen as constituent in the politics of negotiating representations and meanings.

One of the body theory perspectives influential in archaeology relates to the role of the body in the processes of subjectification.

Self-consciousness is realized as the reflexive monitoring of every-day conduct, which proceeds to a large degree at an infra-conscious level [...]. A coherent sense of self-identity and personhood is created and its continuity in time/space sustained by routine and reflexive, yet practical, activities demanding mutual trust between agents, especially those involving the management of the body [...]. This is not to deny that the perception of the body as an objectified image is central to subjectification [...], but to assert the active role of the body in this process. (Treherne 1995, 120)

In this passage, the author puts an important emphasis on the materiality of the body and its undiscursive qualities formed through routinized actions. Treherne mobilizes Bourdieu's and Giddens's arguments with regard to the issue of subjectification. Although this account very usefully conceptualized the interdependence of body, identity and practice, the very argument about the constitution of the body through routinized actions at an infra-conscious level (Giddens 1979; 1984; 1991) and similarly Bourdieu's (1990a; cf. Bourdieu \& Wacquant 1992) notions of habitus, 'bodily hexis' and doxa, can still be criticized for fixing the body within an inescapable matrix of socially-imposed practice. In a sociological analysis of this kind, voluntary and intentional individual actions are excluded as a relevant focus of analysis, and these approaches could still be seen as weak versions of the Foucauldian discursive closure over individual subjectivity.

Treherne (1995) is interested in following the historical trajectory of changes in social attitudes toward the body. Previously, Giddens (1991) addressed questions of subjectivity, embodied self-identity and lifestyle by postulating and building on assumed differences between pre-modern, traditional societies and what he calls high modernity (see also Ariès 1974; Bloch \& Perry 1982). Thomas $(1991,142)$ and Treherne $(1995,122)$ capitalize on this argument when postulating the change from identities more anchored in a social group than within an individual as characteristic of the Neolithic (following Shanks \& Tilley's 1982 interpretation of disarticulated and secondary burials) to a somewhat greater awareness about the bounded entity of an individual self in the Copper and Bronze Ages of European prehistory.

Without denying important diachronic changes in the processes of subjectification, however, Giddens's sharply-postulated difference between moderns and pre-moderns in notions of body, individuality and self-identity can be subject to criticism for its rather essentialist and deterministic dichotomy of separating 'native' and 'modern' bodies. In this view, native bodies are fixed and governed largely by nature and social institutions, which according to this author contrasts with increasingly malleable bodies of high modernity. Thus the so-called traditional societies are all about the group and society and only high modernity is about individuals. Treherne (1995) significantly argues for a prehistoric starting date of the changes with regard to 
individual's self-perception in the process of subjectification by pushing the threshold back to the transition from the Neolithic to the Copper Age. This can hardly be satisfactory. One might need to abandon altogether the search for the origins of human individuation and subjectification, seeing no essential differences between moderns and pre-moderns (Berger 1990; Shilling 1993, 180). Even the typically-rehearsed point about the Western idea of the boundedness of self is perhaps a rhetorically-exaggerated difference, more apparent than real. Thus, in Western society, as among various groups of 'pre-moderns', one can identify figurations of mutually interdependent individuals (Elias 1994; 1983, 209). At the same time, this is not to deny that different cultural contexts impose boundaries to the constitution of self and politics of individuation (e.g. Bynum 2001; papers in Lambek \& Strathern 1998; Meskell 1996, 13).

In sum, discussions about processes of subjectification while rightly emphasizing the materiality of body practice have only assumed and left undertheorized the corporeal materiality and its processuality, which importantly factors in sustaining a coherent self-perception (see below).

Judith Butler is another author who most recently influenced archaeological discussions on the body. Butler's emphasis on the performativity of gender through reciting and inherent subversion of 'regulatory ideals' was of critical influence for feminist theory and its dissemination in the field of humanities and social sciences (also Grosz 1994). Butler's most recognized claim that there is no sex while emphasizing the improvisational, performative character of gender, which allows that different identities can be more or less freely adopted, has most clearly been voiced in Gender Trouble (1990). However, as several critics emphasized since its publication, the problematic aspect of this work relates to the neglected question with regard to the materiality of body, accusing this author of a 'somatophobia' that left the body ignored, negated and disavowed. Self-admittedly, Butler explicitly addresses this criticism in Bodies that Matter (1993), which, while concurring with the Lacanian psychoanalysis, importantly emphasizes the bodily materialization of regulatory schemes along with the improvisational aspects of citationality in the processes of social becoming. Although Butler's approach importantly freed the body in social theory from the discursive closures of the social constructionist heritage, it has never fully succeeded to take the materiality of the body matter seriously. This claim primarily refers to Butler's inability to deal with the corporeal inwardness of the body 'Other'.

\section{Volatile bodies}

Beyond the issues of subjectification and performativity, what has remained undertheorized in current body theory is the issue of the change that the body undergoes over time, and the role of the corporeality of the body in affecting identity change or mutation. This is not to evoke the naturalistic view of the body as a primary source of social patterns and institutions. It is an attempt to consider seriously the Otherness of the body matter itself that constantly destabilizes the form, and to acknowledge and examine this 'tacking' or negotiation between the material resistance of the body and processes of subjectification, i.e. the ways of sustaining/inventing stable images of the self that are always already socially mediated. In the proposed equation we are not only dealing with the realms of social construction and individual subjectification with regard to the body but also with the corporeal Otherness of the body that triggers the change of form.

Anthropologists and archaeologists have frequently looked at the changes that affect the body from the stages of social embodiment that a person undergoes through life, that is to say, as socially-determined ways of becoming a particular person within a particular social context (e.g. papers in Gilchrist 2000; Joyce 1996). Yet this important field of research has been preoccupied by the ways a society regulates the stages of becoming, rarely acknowledging that it is frequently an individual circumstance, a biographical anomaly, and the instabilities of individual bodies can directly affect any cultural fixtures. Moreover, too frequently this field of study has omitted and ignored the indigenous understandings of the world as an unstable universe, full of threatening powers that destabilize any order imposed (Wagner 1980).

In order to sidestep the polarization of sociallyconstructed values and processes of subjectification, we need to address the territory that lies beyond the practices of managing and controlling our bodies through body regimes and the establishment of coherent self-identities. This suggestion refers to the constitutive corporeal matter of our bodies. This dark and forceful territory of the bodily Other is with us in every moment of our lives - the immanence of the physicality of existence - and its unstoppable transformation permanently destabilizes any attempt at fixing our self-perception, social position and the world of shared meaning. One way to explain this position more fully is by referring to the problematization of the change that affects the body in death, focusing both on the individual subject's realization of death 
as well as the way a society deals with death. It is the liminality of death experience, or what Berger, following Karl Jaspers, calls 'marginal situations', that

\begin{abstract}
push us to the borders of our existence; they force into our consciousness knowledge that the human world is open-ended and unstable, and that the meanings we attribute to our bodies and our world are based on nothing more solid than human activity. The major marginal situation is the individual confrontation with death ... death radically questions the taken-for-granted, 'business as usual' attitude which is socially adopted in everyday life (Shilling 1993, 178-9; Berger 1990, 23, 43).
\end{abstract}

This change between different topological orders, i.e. life and death, is only the most radical among numerous mutations of matter that threaten the ontological security of individual subjects in the face of existential anxiety and dread (Giddens 1991 following Kierkegaard). It is the notion of change or mutation that becomes relevant in this context. As Bynum notes: 'We do see change of species; we grapple with change of self. Caterpillars turn into butterflies; dead sticks flower in springtime; beloved children change into killers when schizophrenia erupts; healthy cells become cancer; people die' (2001, 176-7; cf. Griffin 1995). Only by acknowledging the importance of the material mutability and the unstable nature of worldly phenomena are we able to open a very specific perspective in the field of body studies.

What I would suggest in this article is that by focusing on what will be called body metamorphosis, one achieves this problematization of bodily change. It also mobilizes the concept that has had a particular history of usage (see below). By concentrating on processes related to bodily metamorphosis one achieves a necessary balance in the treatment of exteriority, surface, body aesthetic and culturally-imposed norms shared by a collective agency on one hand and individual embodiments and the biographical significance of individual lives on the other hand. The body territory that I sketch by mobilizing the concept of metamorphosis is different from the materiality of body practice and action in the formation of a life style (sensu Giddens) that, for instance, Treherne develops in relation to the Bronze Age warriors (1995). The materiality that I am concerned with is that of the body's radical alterity, which requires constant attempts at social taming, control and mastery in order to overcome the threatening movement of matter. Before I can fully develop this position, however, I must refer to the concept of animality, which is of primary importance in this context.

\section{The night of animality}

One problematic aspect of body theory in general is the predominance of approaches that can be characterized as 'human exceptionalism' (Benton 1991; 1992, 229), which maintain 'that at a certain stage of human evolution, cultural and social capacities emerge which displace the importance of biological mechanisms' (Shilling 1993, 171). This assumption is profoundly flawed and one needs equally to explore social and biological constraints of the body. In this context, I would like to evoke the particular materialism of Georges Bataille and his work on human animality (Bataille 1955; 1986; 1989).

Bataille's anthropological philosophy is characterized by his focus on 'existence as a whole', and this can not be reduced to 'human existence'. His materialism emphasizes the continuity of existence, imposing a limit to its comprehension, in which human birth and sense of identity is a violent separation from the continuous flow of matter - from the 'state of perfect immanence'. Bataille's work has been characterized as being post-structuralist before structuralism and he has been seen as the avant-garde hero of 1960s Parisian circles (Botting \& Wilson 1998, 6). As a fierce critique of Hegelianism, the dialectic of totality and transcendental consciousness, a portion of his work falls under the rubric of animality. By this Bataille sought to penetrate the material and corporeal immanence of our bodily matter, buried under consciousness, exploring the affinity between eroticism and death, sacrifice and excessive expenditure, limit and transgression. Human animality for Bataille refers to an intuitive comprehension about the existence of the 'Other' of our own bodies. We are 'generally mistrusting our bodies, that is, having a deep mistrust of what is accidental, natural, perishable' (Bataille 1993, 91). But the tragic fate of human beings is, according to Bataille, our separation and isolation from Nature, seen as a continuous flow of matter, along with the separation from other living beings - 'exile in the individuated world' (Kwinter 2001, 181) — and at the same time our anguish that forces us to restore the sense of loss that the separation causes. Humankind remains fascinated with the animal's glance - the animal separated from basic matter, as we are, is still one with the world, 'on a level with the world in which it moves like water in water' (Bataille 1989, 25). In the apathy of animal's gaze we approximate continuity and immanence - 'all encompassing night in which the animal bathes' (Kwinter 2001, 178) - i.e. our own death.

Bataille was interested in following this trajectory 
of human separation and fascination with animals and their wild force, which for humans approximated to animality or immanence or immediacy. In his commentary on the cave paintings of Lascaux, and the representation of humans almost exclusively with animal attributes (as hybrids), he writes that:

... Magdalenians [...] being animals no longer, having become men, they now possessed might, power, a position of command. If their efforts obtained worthwhile results, these, they knew, were achieved with the aid of labor and calculation, of which animals are incapable. But to animals they attributed other powers - powers connected with the world's intimate functionings - which, compared to the puniness of human industry, seemed to exert an incomparable force. Hence, to them, it appeared best not to stress their own humanness, signifying no more than the weak power of work, but, to the contrary, to stress an animality glowing with the omnipotence of an impenetrable world: that world's marvelous hidden strength, it seemed to them, effectively nullified, at least in the most decisive manner outweighed all this exhausting toil. As progressively they shook off its crushing burden, they had the feeling of acquiring these superior forces. And so, whenever they could, they sought to evade the monotonous, the shifting regularity of the human order; they would revert to that other world of wildness, of darkness, of bewitching animalism; fervidly, anguish-stricken, they figured that world, struggling for a moment to forget this daylight clarity, this prosaic down-toearth efficacity that was being born in them. (Bataille 1955, 121-2).

Other prehistoric art could be used to explore this argument about the fascination of the force of animalism in the depiction of animals' might. It also highlights the instances of ambivalent forms that human beings take. In the rich inventory of artworks from the Neolithic site of Çatalhöyük in south-central Anatolia, Hodder suggests that the depictions of wild animals and plastered bucrania of aurochs on the internal walls may indicate a communal statement about the taming of and control over the wild (agrios) within the domestic arena (domus) of a building or house space (1990). From the perspective of human animality, however, one may assume that the depictions of animals may rather evoke the sheer, uncontrollable force of depicted animals through the faculty of mimesis (Taussig 1993, 85), signifying the negotiation and struggle with the animals' otherness 'that opens before me a depth that attracts me and is familiar to me' (Bataille 1989, 22).

In a related study, Ingold, discussing animic and totemic cultural traditions of Aboriginal Australia and the circumpolar North, questions the common understanding of indigenous art and animal depic- tions, conventionally seen as symbolic representations of 'hunting magic', and asserts that these artworks should be understood as engaging with the plane of immanence, 'probing more deeply into it and [...] discovering the significance that lies therein' (Ingold $2000 \mathrm{~b}), 112$ ). This reach into the fascinating realm of animality or immediacy (sensu Bataille) is the common underlying theme for both the totemic tradition of Aboriginal Australia, in which animals and humans share the same ancestral land, and also for the animic tradition of the circumpolar North, where the vital force exists in human exchange with the animal world. The artworks of both cultural traditions are thus not representational but serve to reveal this world of immanence, which the animal's gaze conceals.

From this position, prehistoric artworks are not about a representational statement about the current condition of a society but are efficacious and 'powerful' works (cf. Gell 1998; see below), evoking the force of 'the forgotten' (sensu Benjamin). Before examining the salience of the notion of animality as evoked by Bataille for Lepenski Vir depictions, I need to turn more fully to the question of metamorphosis, which is intimately connected to the notion of animality.

\section{Metamorphosis and hybrid beings}

When Gregor Samsa woke up one morning from unsettling dreams, he found himself changed in his bed into a monstrous vermin (Kafka 1968).

Kafka's story The Metamorphosis (1968) can help us to connect the issue of animality with that of metamorphosis. Here, we follow a slow transformation or metamorphosis of the main character Gregor Samsa into a 'monstrous vermin' (Fig. 12). This transformation (Verwandlung) is not a transfer from one realm to another. The Kafkaesque change is one of microscopic events (marginal, insignificant and contextless happenings that multiply into crossroads of possibilities) - petits récits as opposed to grand récits (cf. Lyotard 1984). The change starts suddenly without warning, and it is unclear where it originates. Some of Kafka's early stories evoke the world characterized by 'the impossibility of transcendence (passing to a beyond) and the theme of life as a dying into the world, a rudderless, meaningless wondering without real beginning and end' (Kwinter 2001, 113, footnote 13). The knowledge about change (i.e. slow transformation) in Kafka's world always arrives in the form of rumour - without a clear and fixable origin (Kwinter 2001, 126; cf. García Márquez 1984). It is the world in which metamorphosis is structured by the outside, 

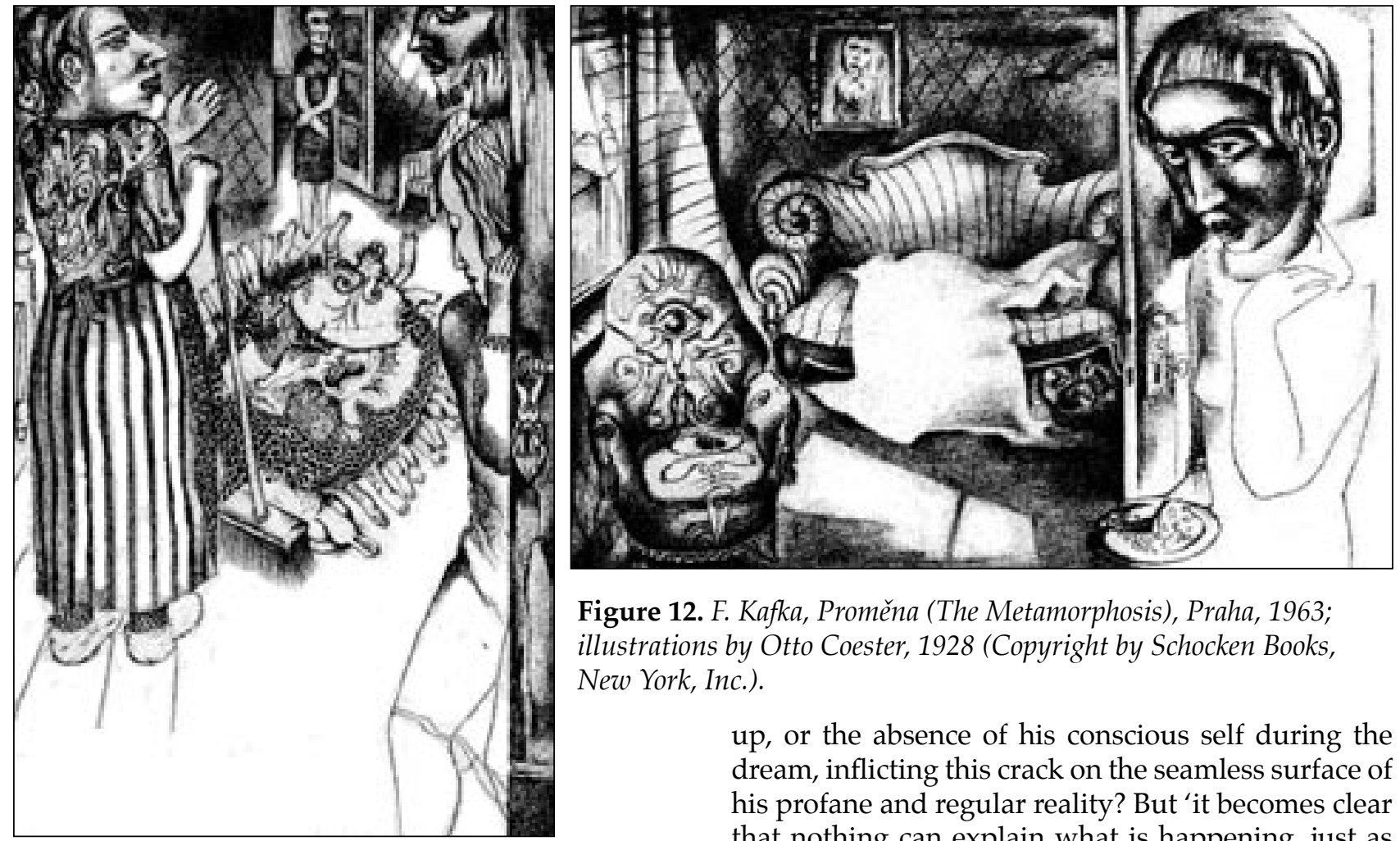

Figure 12. F. Kafka, Proměna (The Metamorphosis), Praha, 1963; illustrations by Otto Coester, 1928 (Copyright by Schocken Books, New York, Inc.).

up, or the absence of his conscious self during the dream, inflicting this crack on the seamless surface of his profane and regular reality? But 'it becomes clear that nothing can explain what is happening, just as nothing could have predicted it', and yet 'nothing in the objective landscape has apparently changed; bed, apartment, family, job, and so on remain entirely and maddeningly regular and intact' (Kwinter 2001, 148). In Kafka's world, Gregor's body and its mutation do not refer only to a bounded and closed locus of self but also to a social body that links actors together in this drama of change. In this way, an important part of Kafka's fiction problematizes the theory of phenomenal ('untimely') change in the world, addressing it from a peculiar modernist perspective. This change is inherent in the labile universe in which the matter is in the perpetual state of becoming (cf. Bergson 1981).

As Kwinter points out '... "animality" constitutes perhaps the central ontological theme in Kafka's universe, characterizing as it does the irreducible, undivided, ineffable "other" world that is contracted in and interpreted with our own' (2001, 145; footnote 6). In The Metamorphosis, the animality is significantly evoked by both Gregor's animal transformation and the explicit mention at the beginning of the story of a framed cutting from a magazine, portraying a woman dressed in furs, that hangs on the wall of Gregor's room (Kwinter 2001; see Fig. 12). As with Bataille's discussion of animality, the animal theme in Kafka's stories presents the world of immanence and immediacy of existence, the realm which humans live alongside, yet from which they remain separated 
- the world in which animals are 'like water in water'. Walter Benjamin asserts that for Kafka 'animals are the receptacles of the forgotten [...] because the most forgotten alien land is one's own body' $(1968,132)$. Thus, Gregor's loss of the ability to use language can refer to his slow departure from the world of human communication, approaching immediacy and immanence (animality), for which human language is profoundly insufficient (cf. Bataille 1988).

The concept of metamorphosis itself has a long and particular history of usage. We first see it in Aristotle's On Generation and Corruption, exploring the processes of becoming. Later, the idea of the mutation of one thing or being into another was celebrated by Ovid in Metamorphoses, asserting the constancy and continuous mutability of the matter that culminates in sexual activity. Ovid strongly emphasizes human animality, asserting that a trace of the former identity can primarily be reflected on the face. (For the significance of face in the process of metamorphosis see the case study below.) A variety of Roman sources also help us to understand similar beliefs of various prehistoric groups in Europe. Miranda Green (1992) provides an insightful analysis of Celtic myths and art that relate to the belief in shape-changing and hybrid beings.

Dante in the Divine Comedy, also, comments on the instances of metamorphosis that he encounters on his voyage into the underworld. In the Middle Ages, the possibility of metamorphosis was extensively debated in theological discussions about the body. St Augustine was at great pains to emphasize the constancy of Form, rejecting the belief in the metamorphosis and radical change (mutatio) of an entity as a change from one state to another. He called it a heresy, the deceptive product of the work of evil demons, and asserted the unchanging core of being (Bynum 2001, 77-86). St Augustine strongly refuted the belief that humans can turn into animals, and claimed 'that such changes are not real (veraciter) but only apparent (specietenus)' (Bynum 2001). Yet this refutation of the concept of mutation did not prevent the proliferation of a literary discourse preoccupied with marvels, i.e. wonders or miracles, especially around the year AD 1200 (Bynum 2001,35, 37-75). This literature explored the possibility of the existence of mutated beings - hybrids - with both human and animal characteristics, influenced by the revival of Ovid. Such a literary genre also reflected a wider concern of those times with the limits of the knowable, 'fear of new identities, fear of boundary crossing' (Bynum 2001, 27) increasingly actualized by the start of colonial explorations. Here, what remains notable is the fascination with narratives that destabilize reality. One of the predominant beliefs and most frequently evoked themes of human to animal metamorphosis toward the end of the twelfth century refers to werewolves, particularly widespread in Europe (cf. Barber 1988), with elements of eroticism.

Bynum distinguishes between two related but different concepts that dominate in these discussions of human-animal transformations - hybridity and metamorphosis $(2001,21)$. Although these are complementary concepts, hybridity refers to a change in which identity, self or form are transformed but not lost, while metamorphosis mainly refers to a complete transformation from one state to another in which the old self dies (metempsychosis) but the traces (vestigia) of the former shape remain (sometimes only as scars - identifying marks left on the body). However, both concepts destabilize the form and 'shake our confidence in the structure of reality, in the basic synchrony between inner and outer we tend to assume' (Bynum 2001, 33). Similar to Kafka, at the heart of the literary tradition preoccupied with the concepts of metamorphosis and animality is the question of the stability of one's own identity through time.

Kafka fears mutation while sleeping and dreaming. Ingold (2000a) describes the intertwined worlds of animal and human beings as reflected in the recorded ethnography of the Ojibwa of central Canada. Here, the constitution of the human self is perpetually threatened by the possibility of 'slipping' into the animal realm. For Ojibwa hunters and trappers, the ability to metamorphose is left to very powerful persons, such as sorcerers and shamans, and for most other humans it would mean death (Ingold 2000a, 93). Importantly, Ingold asserts that it would be misleading to view the process of metamorphosis among the Ojibwa only as a way of putting a clothing or a mask over the unchanged core of the being since this apparent surface is the actual body. Hence ' $t \mathrm{t}] \mathrm{he}$ metamorphosis is not a covering up, but an opening up, of the person to the world' (Ingold 2000a, 94). This is perhaps comparable to Deleuze \& Guattari's 'body without organs', the seamless and continuous surface without hidden depths - the pure intensity, which 'dissolve[s] the very boundary that separates mind from the world' (Ingold 2000a, 100). For the Ojibwa, one's personhood and self are in the continuous movement of becoming in relation with other human and 'other-than-human' beings. The concept of metamorphosis is seen as a way to bridge the distance between one's self in becoming the Other through the faculty of empathy. Thus, Ojibwa animism (cf. Bird-David 1999; Descola 1992) or their notion of animacy enables metamorphosis into those classes of animal beings that are closest to them, animals with which these humans 


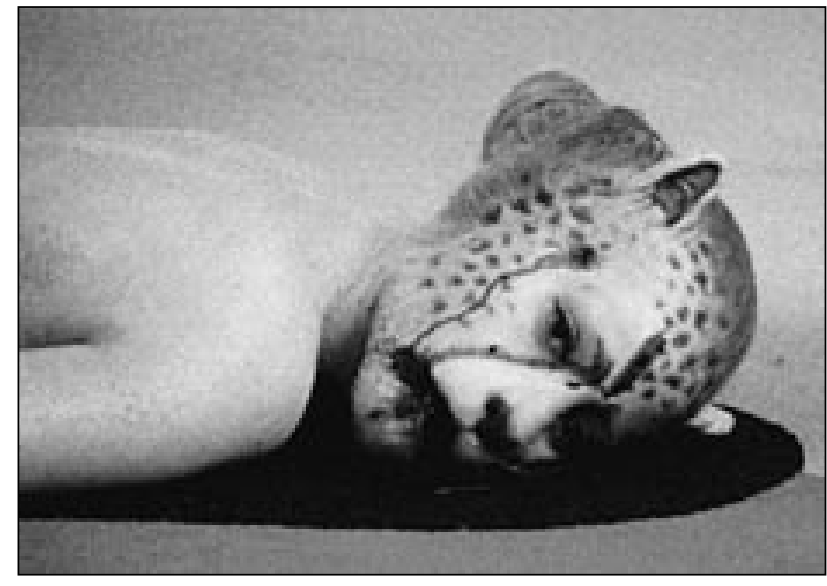

Figure 13. Aimee Mullins as a cheetah-woman, Matthew Barney, The Cremaster Cycle - 'Cremaster 3'.

are genealogically related (Ingold 2000a, 106-9).

We may also consider an example of contemporary art that reveals the world at the plane of immanence by creating an alternative world with strong elements of human animality and with reference to the body. Contemporary multimedia artist Matthew Barney has created this time epic and biographical artistic project The Cremaster Cycle (see the most recent catalogue of the Guggenheim exhibition: Barney 2003). The intertwined themes of metamorphosis and animality (Fig. 13) run strongly in the project that uses a field of heterogeneous materials and sources to enact the reality that lies beneath the superficial world of appearances. The main framework of this project consists of five films/stages (Cremaster 1-5), which evoke for Barney relevant temporal and spatial points (locales) of autobiographical significance. By uncovering the world of immanence and base materiality in which matter constantly transforms (in the scene of horse race in 'Cremaster 3' the movement of the camera reveals the rotting away of flesh on the running horses), Barney exposes his own temporal transformation through the emphasis on his autobiographical cycles. Furthermore, Barney is particularly interested in exploring the moment of sexual differentiation in the physiological development of the human fetus (in the womb). He emphasizes the ambivalence of sexual attributes, volatile gender and bodily transformations, drawing on the ancient theme found in Ovid's story about the nymphs Salmacis and Hermaphroditus who fuse into a single being (Metamorphoses 4.356-88). This emphasis on the metamorphosed body and changes of matter originate in his experience as an athlete, and the way muscles get larger and stronger, transforming the body. The importance of vaseline as the main material in his artistic installations may be connected to its malleable (transformative) qualities - the meta-condition of every type of material matter. The notion of metamorphosis in this project may relate to Barney's interest in Greek mythology, but also to his fascination with Harry Houdini. As Nancy Spector notes, 'Barney's metamorphic vocabulary - in which intangible ideas acquire palpable form, and the distinction between mind and matter disintegrates - invokes the defining characteristics of literary fantasy' (Spector 2003, 23). These alternative fantasy worlds that Barney enacts have a dream-like atmosphere. As in dreams, 'in Barney's epic project, terms like "human", "architecture", "landscape", "vehicle", and "animal" designate not separate entities but zones of interpenetration' (Spector 2003). It is in these zones of interpenetration that one approximates the realms of 'absolute deterritorialization' (pace Deleuze).

By evoking quite diverse sources to sketch the importance of the related notions of body metamorphosis and animality, I suggest that both notions can be used to sidestep the incommensurability of social constructivism and naturalistic approaches by acknowledging the change to the body that comes from 'mute corporeality', confronting the Otherness of the self, transcending essentialisms of naturalist and social-constructionist positions. The metamorphized body, being in a perpetual state of becoming, triggers the proliferation of cultural and social fixtures, attempting to control the openness of the body to its own Other (i.e. animality). In the following section, Lepenski Vir boulders are examined as responses to and conceptualizations of bodily change within a specific cultural context where special links were made to one particular class of non-human being.

\section{Ancestral metamorphosis of the migratory fish}

... nothing perishes in the whole universe; it does but vary and renew form. (Ovid, Metamorphoses 15, 254-5).

Radovanović (1997) was first to explicitly recognize the salient relationship between specific anatomical features of fish on the Lepenski Vir figurative boulders, the behaviour of anadromous fish and a specific burial position/orientation. She asserts that the hybrid fish-human beings represented on some boulders relate to the sturgeon and specifically the largest fish in this family - beluga (Huso huso) (Figs. 9 \& 10). Furthermore, she argues that the annual cycle of sturgeon migration might have been imbued with some significance, and that this connection can be confirmed from burials that are placed in extended positions parallel to the Danube, with their heads oriented to point 
downstream (see Fig. 7). Radovanović suggests that this burial position may relate to a belief held by the community that fish would carry the deceased's soul on its downstream voyage in the autumn and bring it back upon its return next spring.

Taking Radovanović's idea further, one may suggest that the boulder artworks expressed the notion of the corporeal metamorphosis of deceased humans into a hybrid being, reaching the stage of animality in death (sensu Bataille, see above) through the existence of a special totemic relationship between fish (perhaps especially migratory sturgeon) and humans. The temporalilty and scheduling of subsistence activities in the Danube Gorges might have been structured in relation to the seasonal return of migratory fish (Borić 2002a,c). That this specific situation was created in this region in particular may not be coincidental, keeping in mind that the Danube Gorges remained one of the best areas for catching anadromous fish in the much wider region of the Balkans until the first modifications of the riverbed in the nineteenth century (Petrović 1941).

Faunal analyses from several sites indicate the abundance of sturgeon remains (Clason 1980; Brinkhuizen 1986; Bartosiewicz et al. 1995; 2001). Furthermore, although previous faunal reports from Lepenski Vir and Vlasac mention no sturgeon remains (Bökönyi 1972; 1978) re-analyses of fish bones from these sites indicate that sturgeon remains are significantly present both in Mesolithic and Early Neolithic contexts at these sites (Borić \& Dimitrijević in press; Borić et al. in press; Borić 2002c), which means that these species were fished. Stable isotope analyses show high trophic levels in Mesolithic and Early Neolithic diets at the Danube Gorges sites, which might have been due to the significant contribution of freshwater and especially migratory fish (Bonsall et al. 1997; Grupe et al. 2003; Borić et al. in press).

It would be reasonable to assume that Meso-Neolithic occupants of the Danube Gorges sites established an exclusive (perhaps genealogical) connection with migratory fish species, at varying levels of 'closeness', owing to the importance of this fish as a staple food and its specific behaviour (see below). The connection might have had a mythical dimension, boulder artworks being the main medium for expressing this relationship. Although not all boulders maintain naturalistic features of the fish-human hybrid body, their slick and rounded form may directly be related to the body of fish (Fig. 11). Such an assumption would accord with the common understanding that huntergatherers believe in ancestral prey. However, the period when boulder artworks were prolific at Lepenski Vir coincides with the appearance and use of pottery and other Early Neolithic paraphernalia at this site. This suggests that Lepenski Vir does not easily fall into an entirely 'foraging' or 'farming' type of society (Borić 2002b; in press a,b). Domestic animals seem to be absent from faunal assemblages associated with trapezoidal structures, in the Early Neolithic phase at Lepenski Vir (Borić \& Dimitrijević in press). Yet the presence of domestic dogs since the Mesolithic and the awareness of domesticates in the contemporary first farming sites of the wider region might have been partly responsible for increasing explorations of human animality with regard to the particular type of fish prey as objectified on boulder artworks. Perhaps in response to important social changes caused by domestication, the Danube Gorges community might have found it more appropriate and desirable to emphasize and to elaborate on the characteristics of the wild prey than to embrace whole-heartedly all aspects of the changing Neolithic social milieu. In this way, it seems that their identities were at least partly structured with reference to certain wild animal species, possibly relying on and evoking a vital force of the mythical past.

The boulder artworks from Lepenski Vir seem to confirm Ingold's suggestion that instances of art in traditional societies depicting humans and animals are not representations of everyday activities but rather attempts to reveal another plane of reality, one with a dream-like structure, where animals, ancestral and other kinds of beings, and living and deceased humans relate socially to each other in ways that are beyond the reality of the everyday. The Lepenski Vir depictions may relate to animating stages of human metamorphosis, i.e. transformation that occurs in an unstable world of perpetual becoming. Such artworks would embody particular potencies and their creation might have been similarly understood as are the Wandjina artworks (anthropomorphic ancestral beings depicted with large rounded eyes and no other orifices) found in the Kimberleys, northwestern Australia. These ancestral beings 'did not picture themselves on the rock, they painted themselves into it' and, thus, '[i]n the painting, they metamorphosed into their own depictions'; since their 'depiction is a mode of being' (Ingold 2000b, 121).

In the animic tradition of hunting and animal depictions Ingold emphasizes the importance of 'cooperation' between the hunter and the prey, since the meat that can be eaten comes only from the animal that 'intentionally offers itself to the hunter' (2000b, 121). The salience of human-animal cooperation may be significant in the Danube Gorges where a specific link was created between humans and migratory fish 


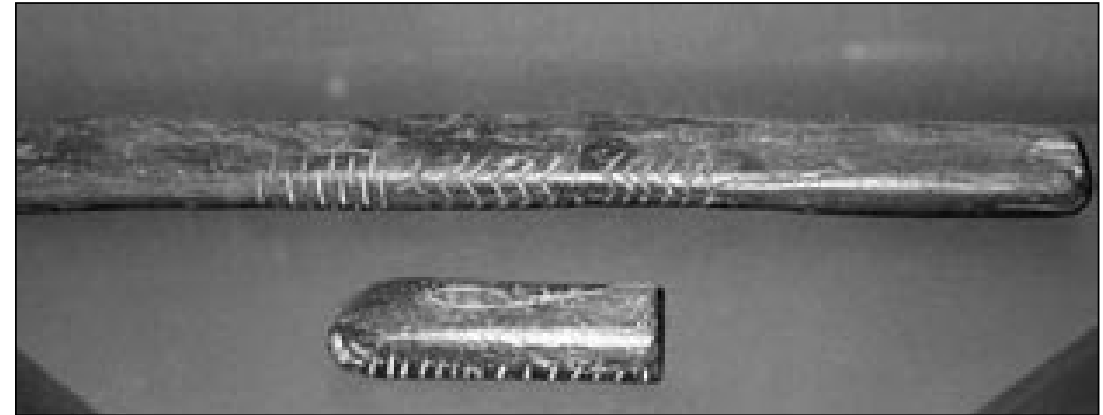

Figure 14. Two engraved fish stunners (that in the foreground with a fish engraving) found in the settlement of Lepenski Vir without precise provenance (photo: Museum of Lepenski Vir).

species, which were the important food staple. Moreover, one behavioural characteristic of sturgeon might have helped to reaffirm the idea that the fish willingly gives itself up to the fishermen. This is described in many hunting/ fishing ethnographies, which refer to sturgeon as very complacent fish, that, once caught in a fishing trap or net by fishermen, rarely tries to escape (Fig. 10). This distinguishes it from other local species of fish, such as catfish or carp. While fishermen in the Danube Gorges in more recent times considered this sturgeon behaviour as stupid (cf. nineteenth-century ethnography of fishing in this region: Petrović 1941), in the Meso-Neolithic context of the Danube Gorges such a complacent character of sturgeon might have been understood in terms of its close relationship with humans, emphasizing a close (possibly even genealogical) relationship between these particular fish beings and humans, sharing the same vital force.

The moment of catching sturgeon (but also other large fish species, such as catfish) is, also, closely related to a particular type of tool found across archaeological sites in this region. Elongated stone clubs were found on the floors of trapezoidal buildings at the sites of Lepenski Vir and Padina, left there after the abandonment of these structures. In a number of instances at Lepenski Vir, carved linear designs and applied red pigment decorated these stone clubs. Dubbed 'sceptres' by the excavator (Srejović 1969; 1972; Srejović \& Babović 1983), they were likely used as fish-stunners, an interpretation that can be supported by various instances of local ethnography where similar elements of fishing equipment were reported (Petrović 1941; cf. Borić 2001, fig. 7; 2002c). One of these tools found in an unspecified context at Lepenski Vir bears a carved depiction of a large fish (Srejović \& Babović 1983, 189; see Fig. 14) and reaffirms their connection to the activity of fishing. I have previously indicated the close affinity between the red colour applied over the surfaces of fish stunners and the contextual sig- nificance of this colour in the region during the Meso-Neolithic periods. It is prominently used, among other things, in the burial context at Vlasac, in the main matrix of limestone floors at Lepenski Vir and is applied over the surfaces of aniconic and carved boulders (Borić 2002a). Thus the elaboration (carvings/notations? and red coloration) of the stone clubs may stem from the use of these implements at the crucial moment of taking the animal's life. The elaboration of these objects might have been related to their use for taking the life of an ancestral being.

Finally, in this context one could propose a connection between hunting or fishing and carving boulders, assuming that in both instances either the hunted (or fished) animal or the material being carved release themselves in the mutual interaction between the agents. In the same way as migratory (ancestral) fish might have been considered to give itself up to the fisherman, a specific boulder form must have been carefully appropriated since 'carving is not the wilful imposition of preconceived form on brute matter, but a process in which the carver is continually responsive to the intrinsic qualities of the material, to how it wants to be' (Ingold 2000b, 126).

In the following sections, the discussion is extended to show how the hybrid beings at Lepenski Vir might have related to particular deceased individuals and age or gender groups. These instances suggest that the aesthetic efficacy of boulder artworks along with the belief in ancestral metamorphosis actively mediated social relations in this society.

\section{Story of the eye: stages of social embodiment at Lepenski Vir}

I will never forget the violent and marvellous experience that comes from the will to open one's eye, facing what exists, what happens. (Georges Bataille, in Preface to Madame Edwarda cited by Foucault 1998, 37)

Let us focus on those instances of boulder artworks from Lepenski Vir that may be called 'representational', i.e. clearly indicating the morphological features of hybrid beings, with mixed fish and human attributes. Studying the iconographic features of these boulders and their contextual associations may make it possible to decode the perception of specific stages of social embodiment. This would relate to the community that occupied/visited Lepenski Vir, and 
might also be of further relevance for the horizontal social structure of the wider community of the region. The analysis particularly benefits from those instances where decorative or representational boulders were placed in relation to a burial within a particular building.

One specific burial group, with both chronological and functional significance can be singled out at Lepenski Vir. This consists of a number of burials that were interred in burial pits cut through limestone floors of trapezoidal buildings, thus post-dating the construction and possibly the use of these structures. That construction and use can be dated to the Early Neolithic period, i.e. c. 6300-5500 cal. BC. Burials 7/I, 61, 26 and 92 (all three placed parallel to the Danube as extended inhumations with their heads pointing downstream), with the addition of c. 40 infant interments.

The old adult male Burial 7/I-a interred immediately behind the hearth of House 22, was accompanied by an aurochs skull at his right shoulder and a detached human skull at his left shoulder, while an ornamented boulder painted red (Srejović \& Babović 1983, 136, cat. no. 30; Srejović 1967, pl. 7) was placed on the forehead of the deceased at floor level (cf. Borić 2003; in press a,b). A

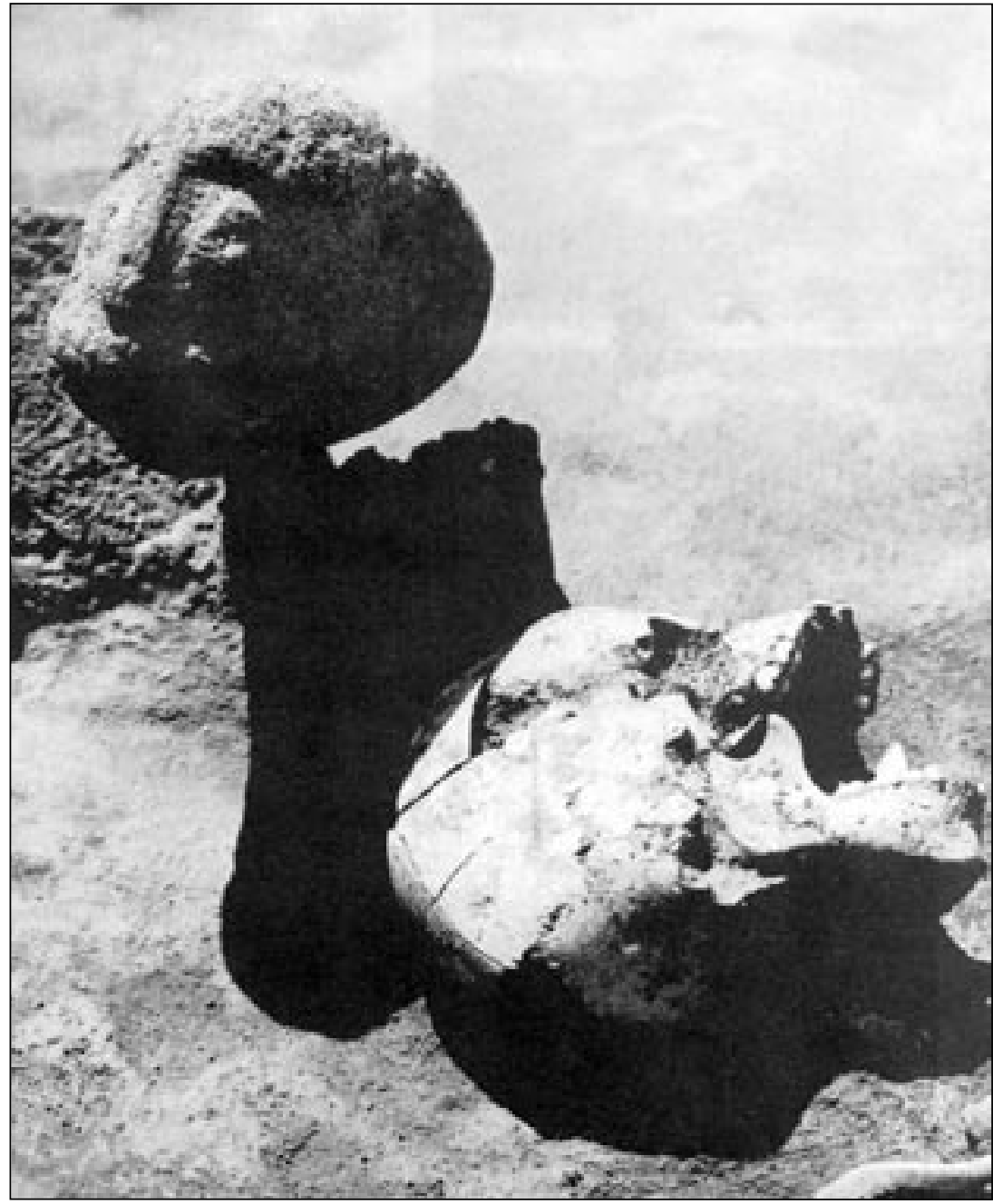

Figure 15. Boulder 'Mermaid' found above the head of Burial 61 in House 40 (Srejović \& Babović 1983, 75, 108). young adult male, Burial 26 in House 34, was similarly placed close to the hearth (cf. Srejović 1969, fig. 65-6; Srejović \& Babović 1983, 108). Although no boulder accompanies this individual, its skull is detached from the mandible and the rest of the body and has been intentionally turned to face the Danube (i.e. to the East), while the rest of the body lies parallel to the river. Child Burial 61 (c. 7 years old) was placed more towards the rear of House 40. Immediately above the head at floor level, a representational boulder was found (Srejović 1969, fig. 65; 1972, fig. 59; Srejović \& Babović 1983, 108; see Table 1, Fig. 15). While this extended inhumation was placed parallel to the Danube, the boulder that commemorated this individual was turned to face the Danube (i.e. to the East). Thus one could recognize a formal similarity in the skull vs. boulder treatment associated with Burials 26 and 61. Such treatments may relate to a specific mortuary rite or religious practice, possibly of chronologically restricted duration, or to similar circumstances of death, membership of the same genealogical group, or other factors. One should add that the practice of detaching the skull and/or mandible from the rest of the body is one of the characteristics of mortuary rites in this region, and is also present at other sites. It seems that this practice can also be related to another burial relevant for the present discussion - child Burial 92 (c. 2 years old) found without the skull; only the mandible and postcranial skeleton were placed below floor level at the rear of House 28 (Stefanović \& Borić in press). On the floor of this building, partly overlapping Burial 92 was a large slab-like stone block with two flanking sculpted boulders at its sides (Srejović 1969, fig. 24; 1972, fig. 14; Srejović \& Babović 1983, 107; Fig. 16). One of these boulders with representational features is further discussed below. Finally, c. 40 infant 


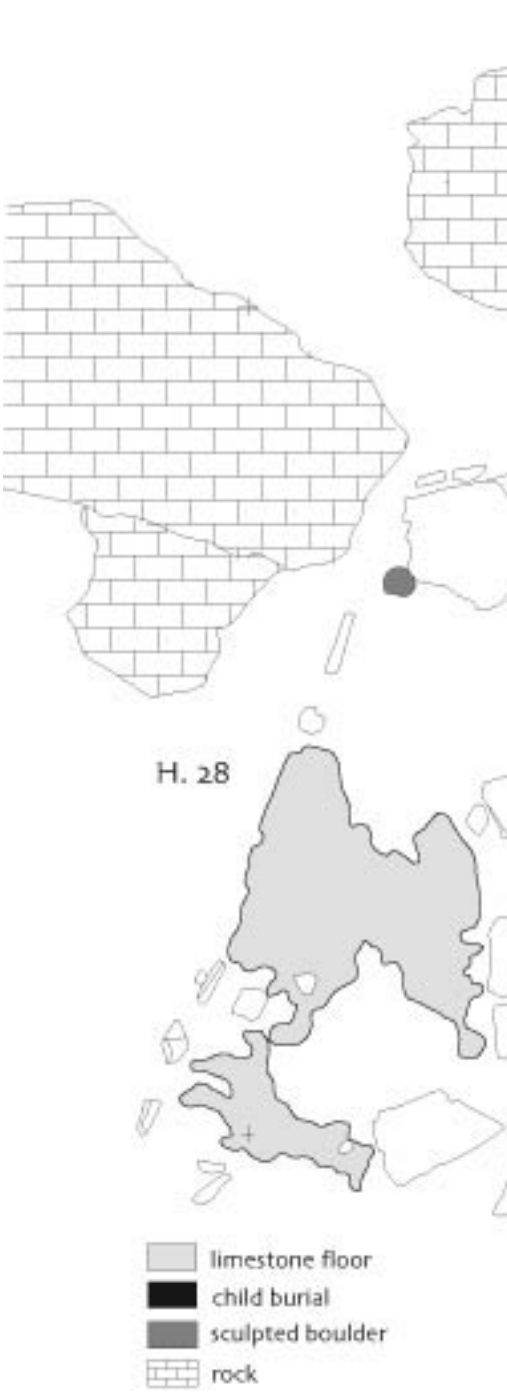

burials were placed in burial pits cut through 19 building floors at Lepenski Vir, almost without exception at the rear of the buildings (Borić \& Stefanović 2004; Stefanović \& Borić in press).

From the archaeological context of these burials, I am inclined to draw correlations between the age of the individuals and the iconographic elements depicted on sculpted boulders associated with some of the burials. Such correlations may elucidate particular stages of social embodiment in this community.

1. As a rule, infant burials were placed at the rear of buildings and no infant burial was ever associated with a boulder.

2. The youngest individual at Lepenski Vir to be associated with a sculptured boulder is a child Burial 92 (c. 2 years old). One of the flanking boulders above Burial 92 on the floor of House 28 depicts a human/ fish face (Srejović \& Babović 1983, 107,

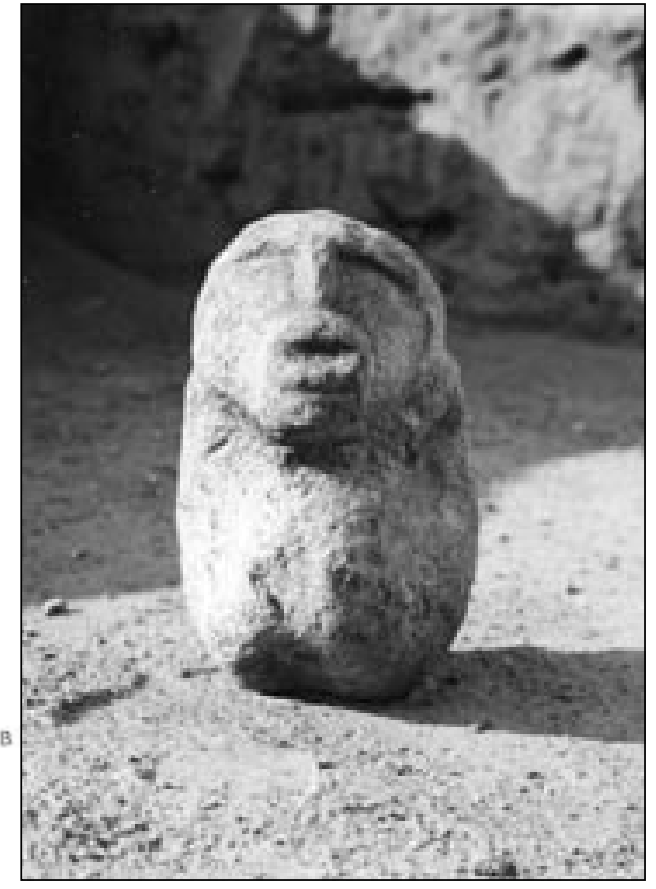

Figure 16. House 28 and child Burial 92 (after Stefanović \& Borić in press, fig. 18), with associated Boulder 'Adam' (no. 1) (Srejović \& Babović 1983, 69, 107). cat. no. 1; Fig. 16). This smaller boulder has an engraved, slightly downturned open mouth and schematic nose. The main difference from other boulders is the way the eyes are represented. Instead of circles, two horizontal lines were carved in raised relief, possibly indicating eyes that are closed. Almost all other representational boulders found at Lepenski Vir have the eyes represented as carved circles (cf. Srejović \& Babović 1983). If the connection of this boulder and Burial 92 is not coincidental, the boulder may depict the stage of social embodiment of the deceased child.

3. Another instance in which a boulder directly commemorates the deceased is Burial 61 in House 40. Placed directly above the head of the 7-year-old child is a small sculpted boulder with a human (child?) face showing a schematic open mouth, nose and engraved eye circles, while relief elements 
were painted with red pigment (Fig. 15).

One is compelled to notice the pattern that connects these younger age groups and faces depicted on associated boulders. Neonates/infants are not as a rule associated with a boulder. The 2-year-old child has eyes depicted closed and the 7-year-old child has eyes depicted as small circles. All other large representational boulders at Lepenski Vir had eyes depicted as circles. Yet no burial from an older age group was directly associated with a representational boulder in such a way as to confirm the significance of these correlations. Three large representational boulders found in the largest building at the site, House 57 / XLIV (Fig. 5), had, in addition to engraved eye circles, semi-circular carved lines in raised relief below the depicted eyes (Srejović \& Babović 1983, 113, 116, 118), perhaps as schematic depictions of eye bags (Figs. $11 \& 17$; see also Fig. 8), which, following the same logic, might indicate rather elderly beings.

Whatever the interpretation of these instances, one can suggest that the eyes on the representational boulders from Lepenski Vir were likely particularly sensitive in conveying social messages and meanings. Anthropological discussions concerning the treatment of artworks emphasize that eyes are frequently seen as 'orifices' that first open up the aniconic form of an idol, signifying beyond their representational significance (cf. Gell 1998, 132, 147). They can be connected with the notion that through the eyes one can penetrate into the mind, into the invisible 'inwardness' of an idol (Gell 1998, 132). Out of all the representational features of a sculpted face, the eyes can be considered the most strongly expressive for depicting personhood.

These instances of correlations between certain age groups and the iconography of boulders at Lepenski Vir may depict stages of social embodiment, i.e. of the process of social 'becoming' through an ideal individual lifecycle. It seems that for the community that used this site, the deceased infants were a sociallysignificant group, and hence their association with trapezoidal buildings. At the same time, they could not have been commemorated by boulders since, most likely, individuals of this age group were not considered full members of the society, and lacked a required stage of social embodiment. This perception of newborns might have been similar to that of the Vezo of Madagascar, who consider newborns as 'boneless' and still not fully human (cf. Astuti 1998). At Lepenski Vir, by the age of two or later, the child was meaningfully connected with a representational boulder, yet the eyes are represented closed. The child might still have lacked the full socially-developed personhood, although was already socially recognizable in the community. Metaphorically and socially, at the time of death the worldly persona of this child was not fully formed, and hence the eyes could not have been represented open, facing the world. Only around the age of seven, when commemorated with a boulder, the eyes of the deceased were carved as circles, possibly indicating that at the time of death $\mathrm{s} /$ he had already reached a socially-recognizable personhood, perhaps as a consequence of rites of passage (cf. van Gennep 1960; Turner 1974) already experienced on the way to adulthood.

Although the larger boulders with semi-circular carved lines below the eye circles (representations of eye bags?), are not connected with particular burials, their size, the very elaborate execution of their body form, their sex/gender attributes (see below) and their colouring with red and dark pigments (Borić 2002a; see Table 1, Figs. 8, $11 \& 17$ ), allow us to speculate that they may be objectified stages of a belief that adults or elders metamorphized into sturgeon fish ancestors. If understood in this way, the boulders with specific depictions of eyes would relate to yet another specific stage of social embodiment, one connected with the age group of old adults and the community elders.

It may be fair criticism to remark that this interpretation rests on an unrepresentative sample of described instances. Rather than isolated outliers, however, the observed connections between particular age groups and specific iconographic depictions on particular boulders provide a significant glimpse into life-cycle stages in this community (Fig. 18). Furthermore, it is not to be expected that practices in which boulders commemorate particular burials and depict a specific age stage of a particular deceased individual would be as clear-cut and neat as we would necessarily need them to be for a statistically significant patterning. There are additional 'complications' with this pattern. Thus, old adult Burial 7 / I-a in House 21 and Burial 4 (see Table 1, nos. 29-30) had boulders placed on their foreheads, but of a non-representational kind, ornamented with a carved spiral and coloured with red pigment (Srejović \& Babović 1983, 135-6), while adult male Burial 26 in House 34 was not commemorated with a boulder. One may ask why old adult individuals buried in trapezoidal buildings are not commemorated by large representational boulders, which might have depicted elders, and what might be the significance of a peculiar accumulation of boulders of this type in House 57 / XLIV (Fig. 5)?

Both the possible patterning and the odd outliers' likely reflect the reality of culturally-prescribed and voluntarily-expressed actions over the long-term. What we are able to observe at Lepenski Vir are in- 


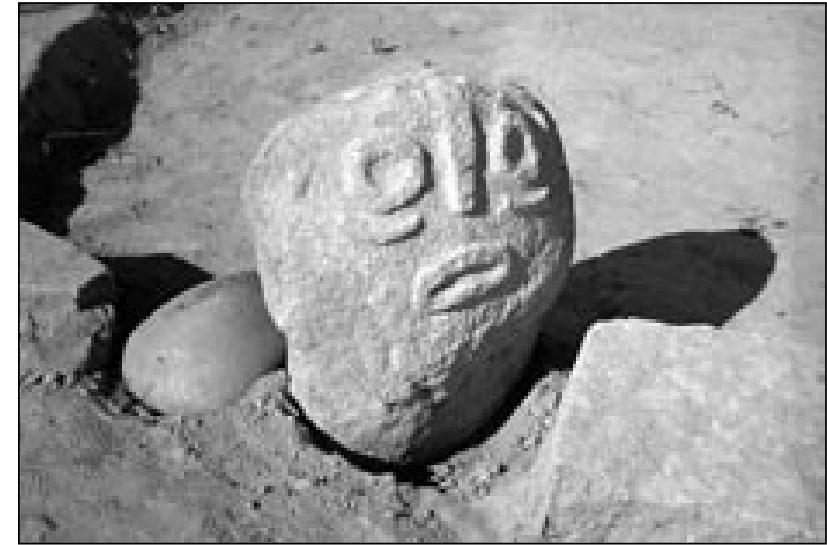

Figure 17. Boulder 'Progenitor' (no. 7) behind the hearth of House XLIV/57, Lepenski Vir (Srejović 1967, pl. 20).

evitably fragmentary indications of cultural rites that were changing over time. There are, however, additional relevant patterns relating to gendered depictions on representational boulders, which can in turn be connected to the spatial ordering of human burials in trapezoidal buildings.

\section{Engendered boulders and the social mapping of building space}

In the foregoing discussion about the connection of age groups and representational boulders, I have described those burials from Lepenski Vir that are undoubtedly connected with trapezoidal structures. Some important patterning may be observed in the appropriation of building spaces with burials of a particular age group. For individuals placed in burial pits dug through building floors, the rear of the buildings seems to be exclusively reserved for neonates or infants (19 buildings: Borić \& Stefanović 2004; Stefanović \& Borić in press). Child Burials 61 and 92 were buried toward the rear of their respective buildings. This pattern seems to be the rule for a significant part of the Early Neolithic occupation at the site. In contrast, two adult male burials with similar position and orientation, Burials $7 / \mathrm{I}-\mathrm{a}$ and 26, were placed immediately behind the rectangular hearths of their respective buildings. The connection of these two burials with this particular area of the two buildings may tentatively suggest that this central place of a building was related to adult males. The rear of the hearth is also the area where most of the sculpted or aniconic boulders and mortars were found inserted in limestone floors. Several boulders are also found at the front side of rectangular hearths, however, and these boulders are of particular interest for engendering the space of a trapezoidal building.

Particularly relevant to this discussion is House 57 / XLIV. Here, two representational boulders were found flanking the front of the hearth (Fig. 11), while another such boulder was at the rear of the hearth (Figs. $5 \&$ 17). One of the two boulders at the front (named 'The First Mother': Srejović \& Babović 1983, 114-15) may depict a female being giving birth, with a central engraving of the womb. The other boulder has bone scutes, which are the characteristic of sturgeon carved on the boulder's back (Srejović \& Babović 1983, 116). In addition, with its large mouth, this boulder is the clearest depiction of a beluga (compare Figs. $9,8,11 \& 17)$. Beluga is a source of roe, from which caviar can be made, and which can only be obtained from beluga females that are at least 20 years old (Keckarević et al. 1998). Hence this boulder might have easily been a primarily (adult) female embodiment. The representational boulder found behind the hearth (named 'Progenitor') has none of the features that would help determine its gender (Fig. 17). However, is it a coincidence that the two boulders that could be engendered as females are found at the front of the hearth in this building?

In another building, House 51, a boulder named 'Vulva' (Fig. 19) was placed at one of the front corners of the hearth. It represents the womb and was intensively burned to give its surface red colour (Srejović \& Babović 1983, 123; Borić 2002a, pl. 1). The excavator of Lepenski Vir describes it as a 'vulva before giving birth’ (Srejović 1969, 110; 1972).

These instances may suggest that gendered differences were mapped onto the building space at Lepenski Vir. We may tentatively sketch an ideal scheme that might have characterized the gender structuring of building space (Fig. 20). On the basis of the spatial patterning of representational boulders and burials of different age groups, I suggest that the front of the hearth was primarily related to the sphere of (adult) women, the space behind the hearth was associated with adult men, and the rear of buildings with infants/children. This is a very simplified scheme and it is based on the qualitative grounds, i.e. by looking at a limited number of 'telling' instances at this site. Furthermore, even if one accepts this 'ideal' structuring of building space in gendered terms (cf. Bourdieu 1990b; Lane 1994), the spatial boundaries might frequently have been blurred and negotiated during the practices and rhythms of daily life carried out within each building. Yet structured gender divisions of building space might have been more firmly constrained and fixed once a building was intentionally abandoned or once it became a sacred burial ground or tomb. In this 


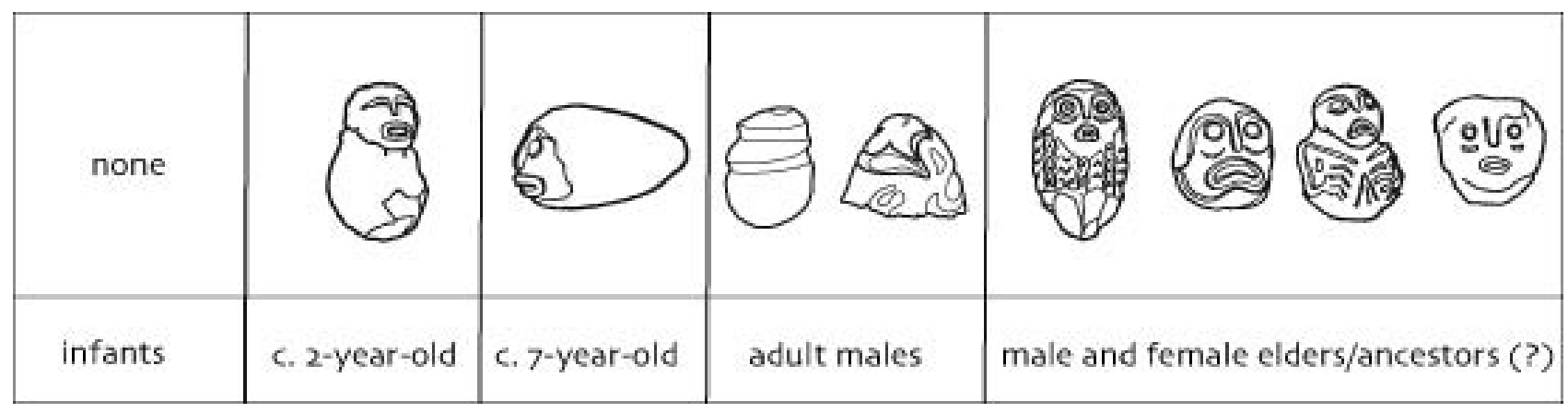

Figure 18. An ideal scheme showing stages of social embodiment associated with particular sculpted boulders at Lepenski Vir.

way the death of houses and people might have firmly fixed the performativity of one's identity-position and gender as well as the improvisational freedom of lived bodies in this cultural context, reinstalling the limits of 'natural' sex (cf. Astuti 1998; 2000; contra Butler 1990).

In sum, it is hardly a coincidence that the only boulders clearly depicting female embodiments were found at the front of the hearths of two buildings at Lepenski Vir. These instances provide a glimpse into the mapping of gendered relations onto the space of the buildings, which was significantly mediated by the spatial ordering of both burials and boulder artworks.

\section{Discussion}

It would be very hard to deny the strong link that the artistic tradition from Lepenski Vir established between the body of fish, the rounded and spherical boulder form and the treatment of the deceased. They hint at the connection between the dead (ancestors) and the river creatures, whose significance went beyond that of a subsistence resource. Such features suggest the possibility that these boulders be viewed as volatile bodies. The ornamentation carved over their surfaces constantly destabilizes the initial aniconic, rounded form of possibly sacred boulders. If this suggestion is accepted, the boulders might have acquired a relational, powerful social agency, as switch points between the worlds of immediacy, animality and death, and the world of the living.

In an essay about the iconography of artworks of the Walbiri of central Australia, Nancy Munn emphasizes that artworks can be seen as a process of revealing and opening up of that which lies beneath the surface, understood as efforts to 'pull out' an ancestral force from the immanent reality of Dreaming that lies beneath the surface of the earth $(1973,198)$.

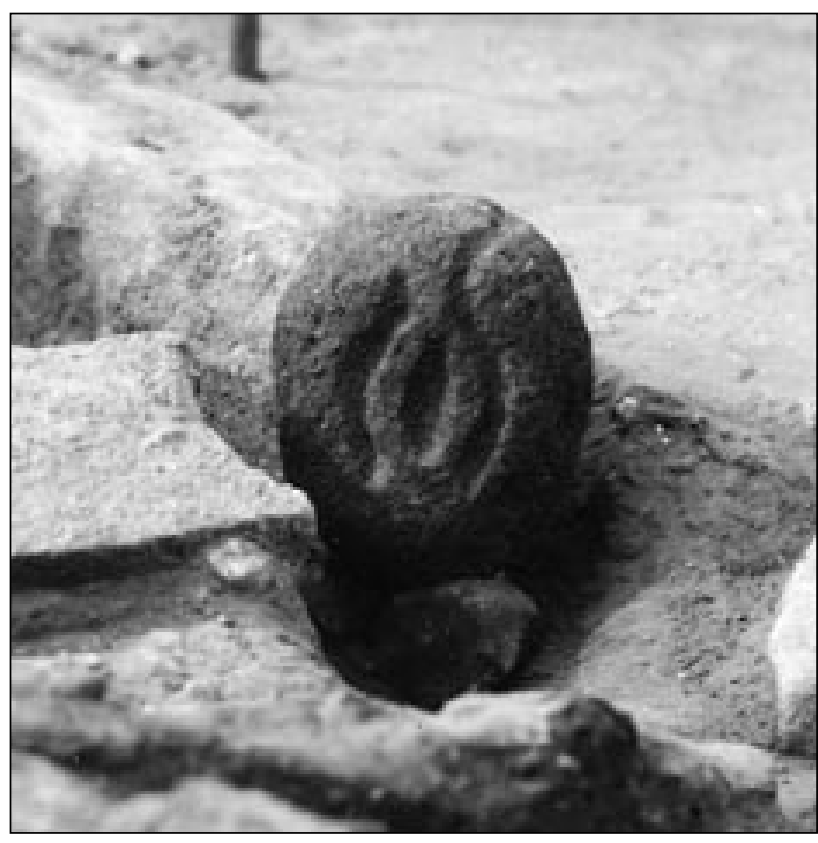

Figure 19. Boulder 'Vulva' (no. 18) in front of the hearth of House 51, Lepenski Vir (Srejović \& Babović 1983, 123).

On the other hand, among the Inuits of northern Quebec the violation of a subtle balance between animals and humans, which exchange vital substance, may cause potential danger to the hunter and even lead to his own death in the encounter with the animal's real face, i.e. its inner being. In this cultural context, the importance of depicting the face of an animal (i.e. the true face of the inner being of an animal that comes out beneath the unstable bodily form in the form of skin), is reflected in the production of masks that reveal 'the underlying character and personal idiosyncrasies attributed to the spirit,' which took the form of a certain animal (Ingold 2000b, 124). As in these instances, by carving the artworks from Lepenski Vir the force embodied in a rounded boulder might have been 'pulled 


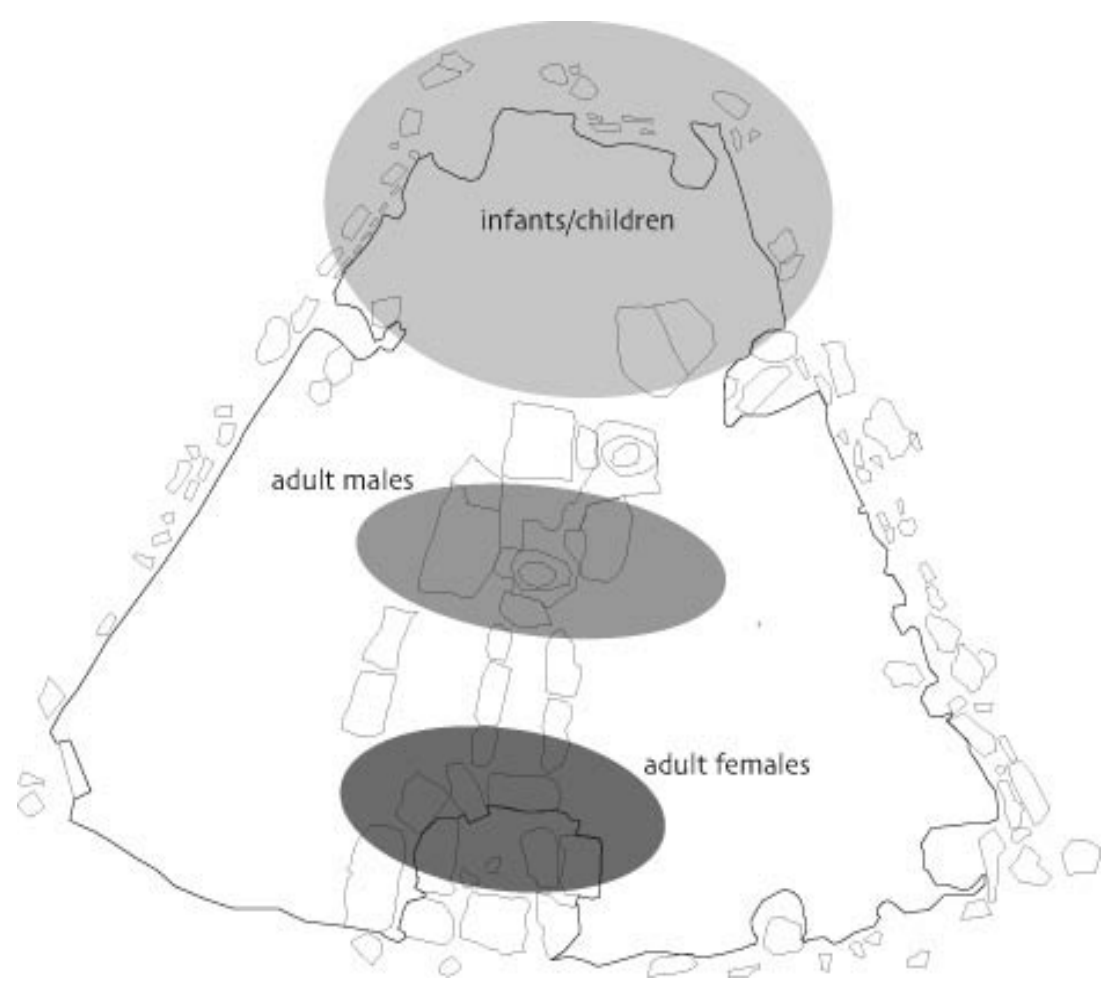

Figure 20. An ideal scheme underlying the division of building space in gendered terms on the basis of representational boulders and burial positions at Lepenski Vir.

out' from its aniconic form, in this way entering and exposing the parallel world of animality, revealing the unstable reality of being and becoming through processes of body metamorphosis.

One wonders whether these insights into the cognitive structure of the community of the region can meaningfully be connected with particular historical episodes and processes? Does the concentration of large 'representational' boulders, which dramatically face one another in House 57 / XLIV (Fig. 5), relate to the use of this building in the final phase of occupation at the site, before its abandonment? How distant and different were the meanings assigned to these boulders by those people who placed them in this building from those of the men/women who carved them, or of those who produced earlier boulders found in other buildings?

It is also worth keeping in mind the social reality of power dynamics in the region, i.e. that the greatest variety of boulders and the only representational boulders were found at Lepenski Vir. This site, possibly a central place for a wider region, might have occupied a particular position in the social hierarchy of the Gorges in depicting, mediating and preserving the communal attitude toward the migratory fish and the human-fish metamorphosis. Collective understandings, meanings and the significance of the boulders were as much formulated at the house-level as shared between people whose identities and social affiliations were structured around particular buildings.

When looking at the variety of human actions and the possible meanings of boulder artworks from Lepenski Vir and other sites in the Danube Gorges over the long-term, assurance remains that they are the expression of a specific artistic, collective oeuvre, sharing various formal elements of a unique style (cf. Gell 1998). This expression of a 'collective mind' might have evolved over several centuries while preserving the social potency associated with their apotropaic and numinous function (Srejović 1969, 122; Borić 2002a; 2003). 'Apotropaism' is here identified as a 'technology of protection' that might have been a constitutive part of the epistemological and ontological grounding of the 'common sense' of these communities, understood as a culture system - 'the paradigmatic form of vernacular wisdom' (Geertz 1983, 90).

At the same time, it would be hard to imagine that these boulders served only one function - be it the ideological integration of the community against a farming ideology and religious beliefs, as suggested by some authors, or the protective qualities of sacred heirlooms. Their meanings, function and potency were likely refigured through their biographical trajectories intertwined with those of various individuals that belonged to particular buildings at the site during the several centuries of its occupation. What these artworks undoubtedly convey, regardless of the multiplicities of their immanent functions and meanings, is a universal and cross-cultural interest, shared by the collectivity at Lepenski Vir, in the instability of form, the transformational character of being, and the forceful potency that lies therein.

\section{Conclusion}

The notions of body metamorphosis and animality have here been problematized by looking at the tradition of boulder artworks found primarily at the 
Meso-Neolithic site of Lepenski Vir. The boulder artworks of this culture tradition might have objectified complex webs of social and genealogical relations between humans and migratory fish, and related to beliefs in metamorphosis, connecting animal and human worlds. These early explorations into the nature-culture, body-mind dichotomies coincide with a time when people might have increasingly explored the issue of animality during the processes of the domestication of animal and plant species.

Art-historical and aesthetic approaches proved unsatisfactory in the analysis of this artistic tradition. Instead, I have drawn on anthropological approaches suggested by Alfred Gell and Tim Ingold for the study of non-Western and pre-modern 'depictions', i.e. 'artworks'. Rejecting the primacy of representationalist interpretations for the artistic tradition from Lepenski Vir, it has been suggested that this art can better be understood by looking at contextual archaeological relations. On the basis of such an analysis, a reconstruction has been attempted of the structure of social embodiments and of social space in the trapezoidal buildings of Lepenski Vir during the Early Neolithic occupation of this site (c. 6300-5500 cal. BC).

The body-like character of boulders and the depiction of hybrid human-animal features on some of these artworks, are a central place to notions of body metamorphosis and animality as explored in various forms by George Bataille, Franz Kafka and Mathew Barney, among others, emphasizing the importance of these notions for a diverse field of body studies. On the one hand, the notion of animality can importantly be used to problematize and conceptualize the base materiality of the body territory, taking its corporeal alterity seriously. The notion of body metamorphosis can also be a way to describe the processuality of the body and identity, affecting individual embodiments and their subjectification through time, which are socially mediated and 'tamed' through idealized life cycle stages.

By focusing on the issue of body metamorphosis and animality, one connects problems that preoccupied prehistoric collectivities and traditional societies across the world with the concerns expressed in the works of individual artists of the Western high culture. These concerns refer to the constancy of form and being, i.e. to the question what lies beneath the superficial world of appearances. In this way, one can move beyond current theoretical debates preoccupied with the issues of subjectification and performative identities, which remain only marginally interested in the corporeality of the body. Following recent artistic statements in Mathew Barney's project, who probes into 'formless' and dream-like worlds while emphasizing the volatile nature of the body and social becoming, the salience and social efficacy of boulder artworks from Lepenski Vir might have lain in their expressiveness of revealing, exposing and opening up - sketching the territory of animality. They embody complex beliefs about the connection between animals and humans, that share the same substance of being, which changes form in the perpetual movement of matter.

\section{Acknowledgements}

This article was largely written during my 2002-2003 postdoctoral fellowship at the Center for Archaeology, Columbia University. I am particularly grateful to Lynn Meskell, Terry D'Altroy and Nan Rothschild for the wonderful opportunity to experience the intellectually-stimulating and inspiring atmosphere of Columbia and New York City. I would like to thank Anna Boozer, Bryan Hanks, Andy Jones, Carrie Nakamura, Jovana Stokić, Lindsay Weiss and two anonymous reviewers for their very useful comments on earlier drafts of this article. The information about the weight of the boulders and mortars I owe to Andrej Starocić. I am also grateful to Chris Scarre and Dora Kemp for all their editorial help.

Dušan Borić
Department of Archaeology
University of Cambridge
Downing Street
Cambridge
CB2 3DZ
UK
db231@cam.ac.uk

Notes

1. The unmodified and modified sandstone boulders from Lepenski Vir originate from the upper reaches of the Boljetinska River, a tributary of the Danube, in the immediate vicinity (downstream) of Lepenski Vir (see Fig. 2). These boulders were found in this area around $10 \mathrm{~km}$ from the site (Srejović 1969, 94) and are described as red Permian sandstones that were eroded from the Šomrdo Hill, transported by the Šomrdo and Strakovica streams to the Boljetinska River (Radovanović 1996, 140). Their colour includes hues of white, yellow and red. Some boulders were treated by applying red or dark pigment over their surfaces, and were also exposed to fire, which, owing to the level of oxidation, produced red and black staining (see Table 1). Unornamented and ornamented mortars were made from less spherical boulders.

2. Aniconic boulders and boulders and mortars ornamented by decorative motifs were also found at the sites of Vlasac, Padina and Hajdučka Vodenica on the right bank of the Danube and only at Cuina Turcului (in a secondary context) on the left bank of the Danube 
in this region. No representational or figural boulders were found apart from those at Lepenski Vir. This may relate to the significance and 'power' of depicting the face, which might have been an exclusive right of the Lepenski Vir locale (see the discussion below).

3. It is worth noting the situation at the neighbouring sites of Vlasac and Padina. At Vlasac, an aniconic boulder was found under a slab that covered a pit dug at the rear of Hearth 11 (Srejović \& Letica 1978, 37, fig. 31). This is the only instance at Vlasac where a boulder was clearly associated with the hearth, as with examples from Lepenski Vir. Two other aniconic boulders at Vlasac were more loosely associated with Hearth 20 (Srejović \& Letica 1978, 35-6, fig. 28) and Stone constructions IX (Srejović \& Letica 1978, 41, fig. 38) and XV (Srejović \& Letica 1978, 48, fig. 53). A similar burial of an aniconic (i.e. only marginally modified) boulder, this time in front of the hearth, and in the pit covered by a stone slab, is attested in House 12 at Padina (Jovanović 1969, pl. 17.2). In several other instances at Padina, pits had been dug at the rear of the hearth (Houses 15 and 18) or at the front (House 14). These were sometimes filled with stones but without boulders, while at the bottom of one such pit behind the hearth of House 16, covered by a stone slab, a shallow stone plate was found (Jovanović 1969, figs. 9.2, 12.2; 1971, 27-8, T. IX.2). At the Lower Gorge site of Hajdučka Vodenica, an ornamented greenish (igneous rock) boulder was found at the level of an earlier (removed) hearth construction, while another (sandstone) boulder was at an upper level in front of the rectangular hearth (Jovanović 1966, T. II.1-2; 1984, 307-8). Two massive boulders of greenish silt (one is an 'aniconic' altar) at Cuina Turcului were from a 'postPalaeolithic layer', in a pit (Păunescu 1978, 51, fig. 26), and were likely in a secondary position.

\section{References}

Ariès, P., 1974. Western Attitudes Towards Death: From the Middle Ages to the Present. Baltimore (MD): John Hopkins University Press.

Astuti, R., 1998. 'It's a boy', 'it's a girl!' Reflections on sex and gender in Madagascar and beyond, in Bodies and Persons: Comparative Perspectives from Africa and Melanesia, eds. M. Lambek \& A. Strathern. Cambridge: Cambridge University Press, 29-52.

Astuti, R., 2000. Kindreds and descent groups: new perspectives from Madagascar, in Cultures of Relatedness: New Approaches to the Study of Kinship, ed. J. Carsten. Cambridge: Cambridge University Press, 90-103.

Barber, P., 1988. Vampires, Burial, and Death: Folklore and Reality. New Haven (NJ): Yale University Press.

Barney, M., 2003. The Cremaster Cycle. New York (NY): Guggenheim Museum.

Bartosiewicz, L., C. Bonsall, V. Boroneanţ \& S. Stallibrass, 1995. Schela Cladovei: a preliminary review of the prehistoric fauna. Mesolithic Miscellany 16(2), 2-19.

Bartosiewicz, L., C. Bonsall, V. Boroneanţ \& S. Stallibrass, 2001. New data on the prehistoric fauna of the Iron Gates: a case study from Schela Cladovei, Romania, in From the Mesolithic to the Neolithic (Proceedings of the International Archaeological Conference held in the Damjanich Museum of Szolnok, September 22-27, 1996), eds. R. Kertész \& J. Makkay. Budapest: Archaeolingua, 15-21.

Bataille, G., 1955. Lascaux or the Birth of Art. Geneva: Skira.

Bataille, G., 1986. Eroticism. San Francisco (CA): City Lights.

Bataille, G., 1988. Inner Experience. Albany (NY): State University of New York Press.

Bataille, G., 1989. Theory of Religion. New York (NY): Zone Books.

Bataille, G., 1993. The Accursed Share, vol. 2: The History of Eroticism. New York (NY): Urzone.

Benjamin, W., 1968. Illuminations. New York (NY): Schocken Books.

Benton, T., 1991. Biology and social science: why the return of the repressed should be given a (cautious) welcome. Sociology 25(1), 1-29.

Benton, T., 1992. Why the welcome needs to be cautious. Sociology 26, 225-32.

Berger, P., 1990. The Sacred Canopy: Elements of a Sociological Theory of Religion. New York (NY): Anchor Books.

Bergson, H., 1981. Matter and Memory. New York (NY): Zone.

Bird-David, N., 1999. 'Animism' revisited: personhood, environment, and relational epistemology. Current Anthropology 40 (Supplement), S67-S91.

Bloch, M. \& J. Parry, 1982. Death and the Regeneration of Life. Cambridge: Cambridge University Press.

Boeckmann, S. \& N. Rebeiz-Nielsen, 1999. Caviar: the Definitive Guide. London: Mitchell Beazley.

Bökönyi, S., 1972 The vertebrate fauna, in Europe's First Monumental Sculpture: New Discoveries at Lepenski Vir, ed. D. Srejović. London: Thames \& Hudson, 186-9.

Bökönyi, S., 1978. The vertebrate fauna of Vlasac, in Vlasac - mezolitsko naselje u Djerdapu II (Vlasac: a Mesolithic Settlement in the Iron Gates), ed. M. Garašanin. Beograd: Srpska akademija nauka i umetnosti, 35-65.

Bonsall, C., R. Lennon, K. McSweeney, C. Stewart, D. Harkness, V. Boroneanţ, L. Bartosiewicz, R. Payton \& J. Chapman, 1997. Mesolithic and early Neolithic in the Iron Gates: a palaeodietary perspective. Journal of European Archaeology 5(1), 50-92.

Bonsall, C., M. Macklin, R. Payton \& A. Boroneanţ, 2002. Climate, floods and river gods: environmental change and the Meso-Neolithic transition in southeast Europe. Before Farming 3-4(2), 1-15.

Borić, D., 1999. Places that created time in the Danube Gorges and beyond, c. 9000-5500 вс. Documenta Praehistorica 26, 41-70.

Borić, D., 2001. Mesolithic and Early Neolithic hunters and fishers in the Danube Gorges: an analysis of archaeozoological data, in From the Mesolithic to the Neolithic (Proceedings of the International Archaeological Conference held in the Damjanich Museum of Szolnok, September 22-27, 1996), eds. R. Kertész \& J. Makkay. Budapest: Archaeolingua, 101-24.

Borić, D., 2002a. Apotropaism and the temporality of colours: colourful Mesolithic-Neolithic seasons in the 
Danube Gorges, in Colouring the Past the Significance of Colour in Archaeological Research, eds. A. Jones \& G. MacGregor. Oxford: Berg, 23-43.

Borić, D., 2002b. The Lepenski Vir conundrum: reinterpretation of the Mesolithic and Neolithic sequences in the Danube Gorges. Antiquity 76, 1026-39.

Borić, D., 2002c. Seasons, Life Cycles and Memory in the Danube Gorges, c. 10,000-5500 BC. Unpublished PhD Dissertation, University of Cambridge, Cambridge.

Borić, D., 2003. 'Deep time' metaphor: mnemonic and apotropaic practices at Lepenski Vir. Journal of Social Archaeology 3(1), 46-74.

Borić, D., in press a. Fuzzy horizons of change: Orientalism and the frontier model in the Meso-Neolithic transition, in The Mesolithic: New Directions and Alternative Narratives, eds. N. Milner \& P. C. Woodman. Oxford: Oxbow Press.

Borić, D., in press b. Deconstructing essentialisms: unsettling frontiers of the Meso-Neolithic Balkans, in Unsettling the Neolithic, eds. D. Bailey \& A. Whittle. Oxford: Oxbow Press.

Borić, D. \& V. Dimitrijević, in press. Continuity of foraging strategies in Mesolithic-Neolithic transformations: dating faunal patterns at Lepenski Vir (the Balkans). Atti della Società per la preistoria e protoistoria della regione Friuli-Venezia Giulia.

Borić, D. \& P. Miracle, 2004. Mesolithic and Neolithic (dis)continuities in the Danube Gorges: new AMS dates from Padina and Hajdučka Vodenica (Serbia). Oxford Journal of Archaeology 23(4), 341-71.

Borić, D. \& S. Stefanović, 2004. Birth and death: infant burials from Vlasac and Lepenski Vir. Antiquity 78(301), 526-46.

Borić, D., G. Grupe, J. Peters \& Ž. Mikić, in press. Is the Mesolithic-Neolithic subsistence dichotomy real? New stable isotope evidence from the Danube Gorges. European Journal of Archaeology 7(3).

Boroneanţ, V., 1970. La période épipaléolithique sur la rive roumaine des Portes de Fer du Danube. Praehistorische Zeitschrift 45(1), 1-25.

Boroneanţ, V., 2001. Paleolithique superieur et epipaleolithique dans la zone des Portes de Fer. Bucharest: Silex.

Botting, F. \& S. Wilson (eds.), 1998. Bataille: a Critical Reader. Oxford: Blackwell Publishers.

Bourdieu, P., 1990a. The Logic of Practice. Cambridge: Polity Press.

Bourdieu, P., 1990b. The Kabyle House or the world reversed, Appendix in The Logic of Practice, ed. P. Bourdieu. Cambridge: Polity Press, 271-319.

Bourdieu, P. \& L.J.D. Wacquant, 1992. An Invitation to Reflexive Sociology. Chicago (IL): University of Chicago Press.

Brinkhuizen, D.C., 1986. Features observed on the skeletons of some recent European Acipenseridae: their importance for the study of excavated remains of sturgeon, in Fish and Archaeology: Studies in Osteometry, Taphonomy Seasonality and Fishing Methods, eds. D.C. Brinkhuizen \& A.T. Clason. (British Archaeological Reports International Series 294.) Oxford: BAR, 18-32.
Butler, J., 1990. Gender Trouble: Feminism and the Subversion of Identity. London: Routledge.

Butler, J., 1993. Bodies that Matter: On the Discursive Limits of 'Sex'. London: Routledge.

Bynum, C.W., 1995. Why all the fuss about the body. Critical Inquiry 22, 1-33.

Bynum, C.W., 2001. Metamorphosis and Identity. New York (NY): Zone Books.

Carsten, J. \& S. Hugh-Jones (eds.), 1995. About the House: Lévi-Strauss and Beyond. Cambridge: Cambridge University Press.

Chapman, J.C., 1993. Social power in the Iron Gates Mesolithic, in Cultural Transformations and Interactions in Eastern Europe, eds. J. Chapman \& P. Dolukhanov. Aldershot: Avebury, 71-121.

Chapman, J.C., 2000. Fragmentation in Archaeology: People, Places and Broken Objects in the Prehistory of South-eastern Europe. London: Routledge.

Clason, A.T., 1980. Padina and Starčevo: game, fish and cattle. Palaeohistoria 22, 142-73.

Deleuze, G., 1990. The Logic of Sense. London: Athlone.

Deleuze, G. \& F. Guattari, 1984. Anti-Oedipus: Capitalism and Schizophrenia. London: Athlone.

Deleuze, G. \& F. Guattari, 1987. A Thousand Plateaus: Capitalism and Schizophrenia. Minneapolis (MN): University of Minnesota Press.

Descola, P., 1992. Societies of nature and the nature of society, in Conceptualizing Society, ed. A. Kuper. London: Routledge, 107-26.

Elias, N., 1983. The Court Society. Oxford: Basil Blackwell.

Elias, N., 1994. The Civilizing Process: the History of Manners and State Formation and Civilization. Oxford: Blackwell.

Featherstone, M., 1990. Consumer Culture and Postmodernism. London: SAGE Publications.

Featherstone, M., 1991. The body in consumer culture, in The Body: Social Process and Cultural Theory, eds. M. Featherstone, M. Hepworth \& B. Turner. London: SAGE Publications, 170-96.

Foucault, M., 1987. Maurice Blanchot: the Thought from Outside, in Foucault/Blanchot. New York (NY): Zone Books.

Foucault, M., 1998. A preface to transgression, in Bataille: a Critical Reader, eds. F. Botting \& S. Wilson. Oxford: Blackwell Publishers, 24-40.

Freedberg, D., 1989. The Power of Images. Chicago (IL): Chicago University Press.

Fuss, D., 1990. Essentially Speaking: Feminism, Nature and Difference. London: Routledge.

Garašanin, M. \& I. Radovanović, 2001. A pot in house 54 at Lepenski Vir I. Antiquity 75(287), 118-25.

García Márquez, G., 1984. Short Stories. New York (NY): Harper \& Row.

Geertz, C., 1983. Local Knowledge: Further Essays in Interpretive Anthropology. New York (NY): Basic Books, Inc., Publishers.

Gell, A., 1996. Vogel's net: traps as artworks and artworks as traps. Journal of Material Culture 1, 15-38.

Gell, A., 1998. Art and Agency: an Anthropological Theory. Oxford: Clarendon Press. 
Giddens, A., 1979. Central Problems in Social Theory: Action, Structure and Contradiction in Social Analysis. Berkeley (CA): University of California Press.

Giddens, A., 1984. The Constitution of Society: Outline of the Theory of Structuration. Berkeley (CA): California University Press.

Giddens, A., 1990. The Consequences of Modernity. Cambridge: Polity Press.

Giddens, A., 1991. Modernity and Self-identity. Cambridge: Polity Press.

Gilchrist, R. (ed.), 2000. Human Lifecycles / World Archaeology. London: Routledge.

Gimbutas, M., 1982. The Goddesses and Gods of Old Europe, 6500-3500 BC, Myths and Cult Images. Berkeley (CA): University of California.

Gimbutas, M., 1991. The Civilization of the Goddess: the World of Old Europe. San Francisco (CA): Harper.

Gosden, C., 2001. Making sense: archaeology and aesthetics, in Archaeology and Aesthetics, ed. C. Gosden. (World Archaeology 33(2)). London: Routledge, 163-7.

Green, M., 1992. Animals in Celtic Life and Myth. London: Routledge.

Griffin, J., 1995. Cosmic leg-pull. New York Review of Books (April 20), 10-14.

Grosz, E., 1994. Volatile Bodies: Toward a Corporeal Feminism. Bloomington (IN): Indiana University Press.

Grupe, G., H. Manhart, Ž. Mikić \& J. Peters, 2003. Vertebrate food webs and subsistence strategies of Meso- and Neolithic populations of central Europe, in Documenta Archaeobiologiae 1. Yearbook of the State Collection of Anthropology and Palaeoanatomy, München, Germany, eds. G. Grupe \& J. Peters. Rahden/Westf.: Verlag M. Leidorf, 193-213.

Handsman, R.G., 1991. Whose art was found at Lepenski Vir? Gender relations and power in archaeology, in Engendering Archaeology: Women and Prehistory, eds. J.M. Gero \& M.W. Conkey. Oxford: Blackwell, 329-65.

Hodder, I., 1990. The Domestication of Europe. Structure and Contingency in Neolithic Societies. Oxford: Blackwell.

Ingold, T., 2000a. A circumpolar night's dream, in The Perception of the Environment: Essays on Livelihood, Dwelling and Skill, by T. Ingold. London: Routledge, 89-110.

Ingold, T., 2000b. Totemism, animism and the depiction of animals, in The Perception of the Environment: Essays on Livelihood, Dwelling and Skill, by T. Ingold. London: Routledge, 111-31.

Jovanović, B., 1966. Sculptures de la nécropole de l'age du fer ancien à Hajdučka Vodenica. Archaeologia Iugoslavica 7, 31-4.

Jovanović, B., 1969. Chronological frames of the Iron Gate group of the Early Neolithic period. Archaeologica Iugoslavica 10, 23-38.

Jovanović, B., 1984. Hajdučka Vodenica, praistorijska nekropola. Starinar XXXIII-XXXIV (1982-1983), 305-13.

Joyce, R.A., 1996. The construction of gender in Classic Maya monuments, in Gender and Archaeology, ed. R.P. Wright. Philadelphia (PA): University of Pennsylvania Press, 167-95.
Joyce, R.A. \& S.D. Gillespie (eds.), 2000. Beyond Kinship: Social and Material Reproduction in House Societies. Philadelphia (PA): University of Pennsylvania Press.

Kafka, F., 1968. The Metamorphosis. New York (NY): Schocken Books.

Keckarević, P., D. Janković \& S. Bogdanović, 1998. The Danube Beluga Story. Paper presented at the 18th Annual Meeting of the International Association for Impact Assessment, 19-24 April 1998, Christchurch, New Zealand.

Kiš, D., 1989. The Encyclopedia of the Dead. London: Faber and Faber.

Küchler, S., 2002. The anthropology of art, in The Material Culture Reader, ed. V. Buchli. Oxford: Berg, 57-80.

Kwinter, S., 2001. Architectures of Time: Toward a Theory of the Event in Modernist Culture. Cambridge (MA): The MIT Press.

Lambek, M. \& A. Strathern (eds.), 1998. Bodies and Persons: Comparative Perspectives from Africa and Melanesia. Cambridge: Cambridge University Press.

Lane, P.J., 1994. The temporal structuring of settlement space among the Dogon of Mali: an ethnoarchaeological case study, in Architecture and Order: Approaches to Social Space, eds. M. Parker Pearson \& C. Richards. London: Routledge, 196-216.

Lyotard, J.-F., 1984. The Postmodern Condition: a Report on Knowledge. Minneapolis (MN): University of Minnesota Press.

Marshack, A., 1981. Epipalaeolithic, Early Neolithic Iconography: a Cognitive, Comparative Analysis of the Lepenski Vir/Vlasac Iconography and Symbolism, its Roots and its Later Influence. Paper presented to 'The Lepenski Vir Symposium', Cologne 1981.

Merleau-Ponty, M., 1962. The Phenomenology of Perception. London: Routledge.

Meskell, L.M., 1995. Goddesses, Gimbutas and New Age archaeology. Antiquity 69, 74-86.

Meskell, L.M., 1996. The somatization of archaeology: institutions, discourses, corporeality. Norwegian Archaeological Review 29(1), 1-16.

Meskell, L.M., 1998. The irresistible body and the seduction of archaeology, in Changing Bodies, Changing Meanings. Studies on the Human Body in Antiquity, ed. D. Montserrat. London: Routledge, 139-61.

Meskell, L.M., 1999. Archaeologies of Social Life: Age, Sex, Class, etc. in Ancient Egypt. Oxford: Blackwell.

Munn, N., 1973. The spatial presentation of cosmic order in Walbiri iconography, in Primitive Art and Society, ed. A. Forge. Oxford: Oxford University Press, 193-220.

Păunescu, Al., 1970. Epipaleoliticul de la Cuina TurculuiDubova. Studii şi Cercetări Istorie Veche şi Archeologice 21(1), 3-29.

Păunescu, Al., 1978. Cercetarile archeologice de la Cuina Turcului-Dubova (Jud. Mehedinti). Tibiscus istorie. Volum inchinat celei de-a 60 a aniversari a Unirii, 11-56.

Petrović, M., 1941. Djerdapski ribolovi u prošlosti i u sadǎsnjosti. Beograd: Srpska Kraljevska Akademija.

Pinney, C. \& N. Thomas (eds.), 2001. Beyond Aesthetics: Art and the Technology of Enchantment. Oxford: Berg. 
Radovanović, I., 1996. The Iron Gates Mesolithic. (Archaeological Series 11.) Ann Arbor (MI): International Monographs in Prehistory.

Radovanović, I., 1997. The Lepenski Vir culture: a contribution to interpretation of its ideological aspects, in Antidoron Dragoslavo Srejović completis LXV annis ab amicis, collegis, discipulis oblatum. Beograd: Centar za arheološka istraživanja, Filozofski fakultet, 85-93.

Radovanović, I., 2000. Houses and burials at Lepenski Vir. European Journal of Archaeology 3(3), 330-49.

Shanks, M. \& C. Tilley, 1982. Ideology, symbolic power and ritual communication: a reinterpretation of Neolithic mortuary practices, in Symbolic and Structural Archaeology, ed. I. Hodder. Cambridge: Cambridge University Press, 129-54.

Shilling, C., 1993. The Body and Social Theory. London: SAGE Publications.

Spector, N., 2003. Only the perverse fantasy can still save us. Mathew Barney in The Cremaster Cycle. New York (NY): Guggenheim Museum, 2-91.

Srejović, D., 1967. Lepenski Vir. Beograd: Narodni Muzej.

Srejović, D., 1969. Lepenski Vir - Nova praistorijska kultura u Podunavlju. Beograd: Srpska književna zadruga.

Srejović, D., 1972. Europe's First Monumental Sculpture: New Discoveries at Lepenski Vir. London: Thames \& Hudson.

Srejović, D., 1981. Lepenski Vir: Menschenbilder einer frühen europäischen Kultur. Mainz am Rhein: Verlag Philipp von Zabern.

Srejović, D. \& Lj. Babović, 1983. Umetnost Lepenskog Vira. Beograd: Jugoslavija.

Srejović, D. \& Z. Letica, 1978. Vlasac. Mezolitsko naselje u Đerdapu (I arheologija). Beograd: Srpska akademija nauka i umetnosti.

Stefanović, S. \& D. Borić, in press. The new born infant burials from Lepenski Vir: in pursuit of contextual meanings, in The Iron Gates Prehistory: New Perspectives, eds. C. Bonsall, V. Boroneanţ \& I. Radovanović. (British Archaeological Reports International Series.) Oxford: BAR.

Taussig, M., 1993. Mimesis and Alterity: a Particular History of the Senses. London: Routledge.

Taussig, M., 1999. Defacement: Public Secrecy and the Labor of the Negative. Stanford (CA): Stanford University Press.

Thomas, J., 1991. Rethinking the Neolithic. Cambridge: Cambridge University Press.

Treherne, P., 1995. The warrior's beauty: the masculine body and self-identity in Bronze-Age Europe. Journal of European Archaeology 3(1), 105-44.

Tringham, R., 2000. Southeastern Europe in the transition to agriculture in Europe: bridge, buffer or mosaic, in Europe's First Farmers, ed. T.D. Price. Cambridge: Cambridge University Press, 19-56.

Turner, B.S., 1984. The Body and Society: Explorations in Social Theory. Oxford: Basil Blackwell.

Turner, B.S., 1991. Recent developments in the theory of the body, in The Body: Social Processes and Cultural Theory, eds. M. Featherstone, M. Hepworth \& B. Turner. London: SAGE Publications.

Turner, B.S., 1992. Regulating Bodies. London: Routledge.

Turner, B.S., 2001. On the concept of axial space: Orientalism and the originary. Journal of Social Archaeology $1(1), 62-74$.

Turner, V., 1974. Dramas, Fields and Metaphors: Symbolic Action in Human Society. Ithaca (NY): Cornell University Press.

van Gennep, A., 1960. The Rites of Passage. Chicago (IL): The University of Chicago Press.

Wagner, R., 1980. The Invention of Culture. Chicago (IL): Chicago University Press.

Whittle, A., 1998. Fish, faces and fingers: presences and symbolic identities in the Meso-Neolithic transition in the Carpathian Basin. Documenta Praehistorica 25, 133-50.

Whittle, A., L. Bartosiewicz, D. Borić, P. Pettitt \& M. Richards, 2002. In the beginning: new radiocarbon dates for the Early Neolithic in northern Serbia and southeast Hungary. Antaeus 25, 63-117.

Yates, T., 1990. Archaeology through the Looking-Glass, in in Archaeology after Structuralism: Post-Structuralism and the Practice of Archaeology, eds. I. Bapty \& T. Yates. London: Routledge, 154-202.

Yates, T., 1993. Frameworks for an archaeology of the body, in Interpretative Archaeology, ed. C. Tilley. Oxford: Berg, 31-72.

Yates, T. \& J. Nordbladh, 1990. This perfect body, this virgin text: between sex and gender in archaeology, in Archaeology after Structuralism: Post-Structuralism and the Practice of Archaeology, eds. I. Bapty \& T. Yates. London: Routledge, 222-37.

\section{Author biography}

Dušan Borić is a Research Associate at the Department of Archaeology, University of Cambridge, England, with special research interests in European and Near Eastern Prehistory and archaeological theory. At present he is researching the nature of changes in beliefs of the human body in early prehistory. His current archaeological field project is based in the region of the Danube Gorges, Serbia. 


\section{$\Delta$ 策回}

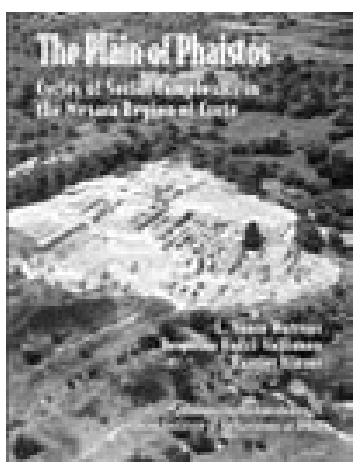

The Plain of Phaistos: Cycles of Social Complexity in the Mesara Region of Crete/ By L. Vance Watrous, Despoina Hadzi-Vallianou, and Harriet Blitzer

A monograph from an interdisciplinary regional field project on Crete (1984-1988), this volume traces the changing patterns of settlement and cycles of social complexity from the Late Neolithic to the present day within the state of Phaistos. The geological, archaeological, environmental, botanical, historical and ethnographic studies presented establish the regional identity of the Western Mesara and attempt to answer how and why the Bronze Age and Classical states arose at Phaistos. $\$ 60$ (cloth)

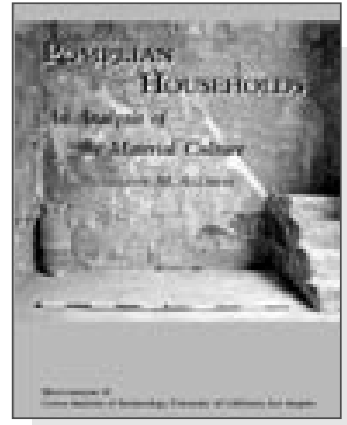

Pompeian Households: An Analysis of the Material Culture / Penelope M. Allison A contextualized and materialsoriented approach to household activities at Pompeii that deepens our understanding of Roman domestic behavior. \$40 (paper)

\section{Foundations of Chumash Complexity / Edited by Jeanne E. Arnold}

This latest research on the foundations of sociopolitical complexity in coastal California focuses on the Chumash as complex huntergatherers with ascribed chiefly leadership, a

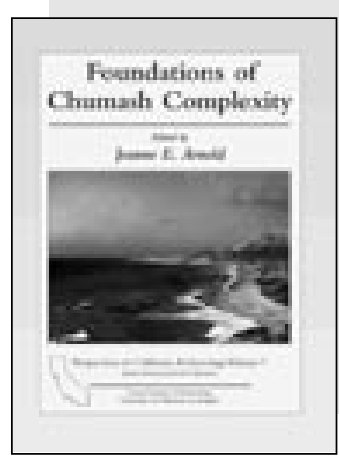
strong maritime economy based on oceangoing canoes, an integrative ceremonial system, and intensive and specialized craft production. \$24 (paper), $\$ 45$ (cloth)

\section{K'axob: Ritual, Work, and Family in an Ancient Maya Village / Edited by Patricia A. McAnany}

A millennial-long record of Formative life reveals a conscious construction of identity and sheds light on the manner in which materiality was manipulated in response to larger political dictates. The accompanying interactive $\mathrm{CD}$ provides complementary materials on a scale never before achieved and includes comprehensive data sets, over one thousand images (both photographs and line drawings), a tour of K'axob, and 3-D models of the excavation units. $\$ 65$ (cloth with multimedia $C D$ )

\section{Advances in Titicaca Basin Archaeology-1/ Edited by Charles Stanish, Amanda B. Cohen, and Mark S. Aldenderfer}

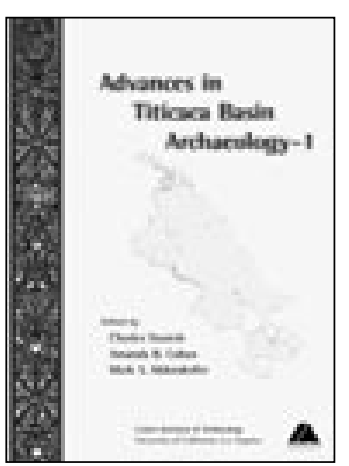

The first in a series of edited volumes on recent research in the circumTiticaca basin of the south central Andes, this volume covers the entire range of human settlement in the region, from the Early Archaic to the early Colonial Period. The 18 chapters represent short research reports as well as longer synthetic essays on recent survey and excavations conducted from Peru to Bolivia. \$25 (paper), \$45 (cloth)

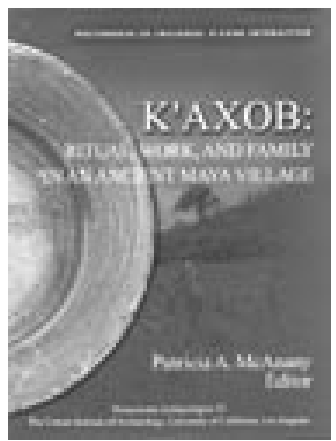

Mention this ad for a 20\% discount (code 146-04)

See our full catalog at: $h t t p: / / w w w . i o a . u c l a . e d u / p u b l i c a t i o n s . h t m$

Now distributed through Oxbow Books David Brown Book Co.

For North American orders, contact: The David Brown Book Co., PO Box 511, Oakville CT 06779

800-791-9354, david.brown.bk.co@snet.net

Outside North America, please contact: Oxbow Books, Park End Place, Oxford, OX1 1HN, UK 44 (0)1865 241249, oxbow@oxbowbooks.com,www.oxbowbooks.com 